Working Paper Series

Essential work and emergency childcare: Identifying gender differences in COVID-19 effects on labour demand and supply

Jordy Meekes

Wolter H. J. Hassink Guyonne Kalb

Working Paper No. 24/20 November 2020 


\title{
Essential work and emergency childcare: Identifying gender differences in COVID-19 effects on labour demand and supply*
}

\author{
Jordy Meekes \\ Melbourne Institute: Applied Economic \& Social Research, \\ The University of Melbourne \\ Institute of Labor Economics (IZA) \\ The ARC Centre of Excellence for Children and Families over the Life Course \\ Wolter H. J. Hassink \\ Utrecht University School of Economics, \\ Utrecht University \\ Institute of Labor Economics (IZA) \\ Guyonne Kalb \\ Melbourne Institute: Applied Economic \& Social Research, \\ The University of Melbourne \\ Institute of Labor Economics (IZA) \\ The ARC Centre of Excellence for Children and Families over the Life Course
}

\author{
Melbourne Institute Working Paper No. 24/20
}

November 2020

\begin{abstract}
*We are grateful to Statistics Netherlands (Centraal Bureau voor de Statistiek, CBS) for providing access to the administrative data. Results are based on calculations by Utrecht University and University of Melbourne using non-public microdata from Statistics Netherlands. Under certain conditions, these microdata are accessible for statistical and scientific research. For further information: microdata@cbs.nl. This research was supported by the Australian Research Council Centre of Excellence for Children and Families over the Life Course (CE140100027). Guyonne Kalb is a Chief Investigator at the Life Course Centre and Jordy Meekes is a Life Course Centre Research Fellow.
\end{abstract}

Melbourne Institute: Applied Economic \& Social Research

The University of Melbourne

Victoria 3010 Australia

Telephone +61 383442100

Fax +61383442111

Email melb-inst@unimelb.edu.au

Website melbourneinstitute.unimelb.edu.au 


\begin{abstract}
We examine whether the COVID-19 crisis affects women and men differently in terms of employment, working hours and hourly wages outcomes, and whether the effects are demand or supply driven. COVID-19 impacts are studied using administrative data on all Dutch employees up to 30 June 2020, focusing on the national lockdown and the emergency childcare for essential workers in the Netherlands. First, we find that the impact of COVID-19 is much larger for non-essential workers than for essential workers. Although, on average, women and men are equally affected, female non-essential workers are more affected than male non-essential workers. Second, partnered individuals with young children are equally affected by the crisis as others, irrespective of gender and spousal employment. Third, singleparent essential workers experience relatively large negative labour supply effects, suggesting emergency childcare was not sufficient for this group. However, overall, labour demand effects appear more important than labour supply effects.
\end{abstract}

JEL classification: J13, J16, J20, J64

Keywords: COVID-19, Gender, Employment, Hours worked, Lockdown, Essential workers 


\section{Introduction}

The extent to which societies have been impacted by COVID-19 is unprecedented in recent times. The COVID-19 economic shock is so severe due to government-imposed lockdowns, that have shut down specific sectors of the economy leading to a decrease in labour demand, combined with the compulsory closing of childcare and schools, that have limited the labour supply of households. As women and men are likely to be employed in different sectors of the economy, facing different labour demand shocks, and are likely to face different childcare responsibilities, an important question is whether (and how) women and men were affected differently by the COVID-19 crisis.

The literature devotes much attention to gender differences in the impact of the economic effects of COVID-19 because the closing of childcare facilities and schools puts pressure on the ability of households to outsource childcare needs (Alon et al., 2020; Fuchs-Schündeln et al., 2020). Both men and women increased time spent in home production, but women increased hours spent on childcare by more than men (Del Boca et al., 2020; Hupkau \& Petrongolo, 2020; Oreffice \& Quintana-Domeque, 2020; Sevilla \& Smith, 2020). As women often take responsibility for the caring roles in the household, they are likely to spend more time on childcare, home schooling and housework thereby leaving less time for hours in paid employment.

In light of these differences in taking responsibility for childcare, this paper aims to determine whether women and men are affected differently by the COVID-19 crisis in terms of labour market outcomes, and whether the mechanisms of the impacts are different (i.e. whether the impact is demand or supply driven). So far, the literature, mostly based on survey data, provides mixed evidence on whether women experience worse labour market outcomes following the COVID-19 shock than men. ${ }^{1}$

\footnotetext{
${ }^{1}$ In the US and UK, women have been affected disproportionately by COVID-19 in terms of job loss, but in Germany there is no evidence of a gender difference in job loss which can be partly explained by the German short-time work scheme and the consequent relatively low number of people experiencing job loss (Adams-Prassl et al., 2020a). For the UK, Hupkau and Petrongolo (2020) show that women and men are equally affected in terms of job loss, but women experience smaller losses in working hours and earnings. Andrew et al. (2020) show for parents in the UK that mothers are more likely than fathers to lose their job, spending less hours on paid work and more hours on unpaid work such as on childcare activities. A similar conclusion is reached by Farré et al. (2020) for Spain. For the Netherlands, Von Gaudecker et al. (2020) use survey data to show that female workers lose one hour more in total working hours than men, whereas Hassink et al. (2020) use administrative data and show that the gender difference in COVID-19 effects on employment, working hours and hourly wages is close to zero until the end of March 2020.
} 
Using administrative data on the entire population of Dutch employees, we exploit a temporary feature of the Dutch labour market. At the start of the lockdown, the Dutch government classified economic sectors as essential or non-essential as part of an emergency childcare policy that only allowed essential workers to send their children to childcare or school during the lockdown. This policy, providing access to childcare for employees in essential economic sectors only, allows us to disentangle impacts on labour supply and demand to some extent.

Our paper examines whether the COVID-19 shock resulted in gender gaps in labour market outcomes. We first isolate demand-side driven gender differences in the effects of COVID-19 by comparing essential employees and non-essential employees, focussing on differences between these two groups resulting from the government's categorisation of work into these two groups. We then analyse the labour supply side effects of COVID-19, focussing on gender differences in the importance of the individual's household composition and their spouse's employment situation for labour market outcomes. We exploit the emergency childcare policy response from the Dutch government that allowed only essential workers, defined as employed in critical or crucial sectors, to send their children to childcare or school during the lockdown from mid-March to May 2020. This emergency childcare policy was implemented to support two-earner households where both earners were essential workers, as announced on March 16, 2020 and in effect until June 30, 2020.

The analysis is based on Dutch individuals who were affected by the crisis using unique monthly administrative microdata from Statistics Netherlands that cover the entire Dutch population of employees in the period until 30 June 2020. Using a monthly panel of individual employees for 2019 and 2020, we study the response of Dutch employees to the COVID-19 outbreak in terms of employment, monthly paid working hours and hourly wages. To study the labour demand and supply effects of COVID-19, a monthly differences-in-differences model is estimated, for four subsamples stratified by essential/non-essential status and by gender. A triple differences specification is estimated to study the importance of employees' household composition (relationship status, presence and age of children) and spouses' employment situation (essential/non-essential status and full-time/part-time status) for the labour supply effects. We estimate this model separately for the four samples, controlling for labour demand effects by including a wide range of observables. 
We contribute to the literature in two ways. First, we contribute to the literature on the gender difference in the impact of COVID-19 on labour market outcomes. Second, we contribute to the literature that relates women's labour market outcomes to household composition, the spouse's employment status and availability of childcare. ${ }^{2}$

Previous COVID-19 research argues that female employees are more negatively affected than male employees, as women are more likely to take responsibility for the caring roles in the household, and they are more likely to work in sectors hit hardest by the effects of COVID-19 (Alon et al., 2020). Indeed, we find that female non-essential workers fare worse in terms of employment and working hours than male non-essential workers. On average, non-essential workers experience a decrease of 1.5 to 2.5 percentage points in employment, of 2 to 3 per cent in working hours and of 1 per cent in hourly wages between April and June 2020. In contrast, we show that female and male essential workers experience similar small effects of COVID-19 in employment and working hours. Importantly, consistent with Lewandowski et al. (2020), we show that, in the Netherlands, women are more likely to be essential workers than men. These findings suggest that the COVID-19 shock did not result in a widened gender gap in employment in the period until June 2020, and labour demand effects appear more important than labour supply effects of COVID-19.

We further show that partnered employees with young children are not affected more by the COVID-19 shock than others, experiencing a similar impact as partnered employees with older or no children. These analyses also show that the COVID-19 effects on employment, working hours and hourly wages of partnered individuals with children aged below 12 years do not depend much on the spouse's employment situation. These results hold for women and men, suggesting the labour market institutions in place - including paid leave entitlements and the Temporary Emergency Measure for the Preservation of Jobs - protects the labour market outcomes of employees with caring responsibilities.

\footnotetext{
2 There is abundant evidence of women's labour market outcomes worsening compared to men's labour market outcomes after becoming a parent (Adda et al., 2017; Kleven et al., 2019; Meekes \& Hassink, 2020). The childcare literature shows the effect of the availability of childcare on the labour supply of mothers (Bauernschuster \& Schlotter, 2015; Havnes \& Mogstad, 2011). Cortés and Pan (2020) provide a comprehensive review of the link between children and gender gaps in labour market outcomes.
} 
Data on the entire population of Dutch employees also enable us to focus on the small subpopulation of single parents who often face disadvantage. The results show that the negative effects of COVID-19 on employment and working hours are particularly large for single parents of young children, both mothers and fathers, working in essential jobs. Specifically, single mothers of preschool children in essential jobs, relative to other female essential workers, experience a 0.5 percentage point larger loss in employment and a 2 to 3 percentage point larger loss in working hours. This finding suggests the emergency childcare policy was not completely successful in limiting negative labour supply effects for single-parent essential workers.

\section{COVID-19 policies in the Netherlands}

The peak in the first wave of the Dutch COVID-19 mortality and infections occurred during late March and early April 2020 (Rijksinstituut voor Volksgezondheid en Milieu (RIVM), 2020). COVID-19 policies by the Dutch government were implemented in early and mid-March. These preventative measures included a lockdown, 1.5-meter social distancing, cancellations of small and large gatherings, and work from home directives. From March 15 onwards, many non-essential industries were directed to close, including restaurants, schools, and childcare and sport facilities. Importantly, on March 16 it was announced that essential workers, i.e. those who are employed in critical or crucial sectors, could still send their children to childcare and school as long as the children did not show any sign of colds, coughs or fever. The government defined these crucial sectors for the purpose of determining eligibility for emergency childcare. Although the government advised that emergency childcare is only for households where both parents are essential workers (or where the single parent is an essential worker), the government also allowed couple households with just one essential worker to use it.

On March 31, it was announced that all measures were to be extended until April 28. On April 22, it was announced that most measures were to be extended to May 20. However, primary schools and childcare facilities were partly reopened from May 11 onwards. Childcare for children aged 0-4 was available fully, whereas primary school students were required to go back to school for about half the time. On May 6, the Dutch government announced that from June 1 onwards, the hospitality sector could 
open their outdoor areas again. On May 19, the government announced that secondary schools and higher education institutions would open again from June 2 and June 15, respectively. From June 8, primary schools resumed regular teaching hours to all children. Based on the above timeline, we hypothesise that the largest negative labour market impact occurred in April and May.

The main support for employers and their employees was the Temporary Emergency Measure for the Preservation of $\mathrm{Jobs}^{3}$ (NOW) allowance, which is a short-time work scheme allowing firms facing reduced labour demand to reduce employees' working hours temporarily. The NOW covers up to 90 per cent of the employer's wage bill for March, April and May of 2020 covering all employee types including those in flexible jobs. An advance payment for 80 per cent of the requested allowance can be made. Eligible companies are those who (i) expect to lose at least 20 per cent of their revenue, (ii) keep employees' gross pay the same as before the COVID-19 crisis and (iii) commit to not fire employees for economic reasons during the period covered by the allowance from March until May 31, 2020.

Announced on March 31, 2020, the NOW superseded the Regulation for Reduction in Working Hours to cope with the significant decrease in employers' labour demand. The Regulation for Reduction in Working Hours was a short-time work scheme that had been in place for over 10 years, and was extensively used by employers to cope with the 2008 Global Financial Crisis, which allowed employers to reduce employees' working hours when facing significantly reduced labour demand for a period of 2 to 24 weeks. The Dutch Public Employment Service covers the salaries of furloughed workers, paying this to the employer who then transfers it to its employees. In June 2020, an extension of the NOW under comparable rules was announced, covering the period from June until September 2020.

\section{Data}

We use administrative data from Statistics Netherlands that cover the entire population of Dutch employees for the analyses. Monthly microdata on labour market outcomes are collected from income

\footnotetext{
${ }^{3}$ In Dutch: "Tijdelijke Noodmaatregel Overbrugging voor Werkgelegenheid".
} 
statements available in the Job and Wages Register over the period 2019 to 2020 using the calendar months January to June. The data are based on employed workers' monthly income statements.

\subsection{Key variables}

The key outcome variables include employment (yes/no), monthly paid working hours and monthly hourly wage. The indicator variable employment equals one for the employed even if they currently work zero hours, and zero for the non-employed. The number of paid working hours is unaffected by paid leave, holidays and overtime hours, but is reduced when employees are furloughed, work fewer hours, and/or take unpaid leave. Hourly wage is computed by dividing monthly gross wages by monthly working hours. We analyse the natural logarithm of these two outcome variables, only including values larger than one to avoid outliers. ${ }^{4}$ As a robustness check, the variables hourly wages and working hours are used in levels and set to zero in the months where individuals are non-employed, to include all observations; thus limiting selection into non-employment effects in our analyses.

All covariates included in the model are measured in the reference month of February of the given calendar year or at the end of the previous year and kept constant over the year, ensuring they are measured before the COVID-19 shock. Demographic and household characteristics are as observed on 31 December of the previous year, including data on the individual's gender, date of birth, country of birth (Netherlands: yes/no), marital status (married or de facto partnership versus single), presence and date of birth of the youngest child; and residential location at the provincial level (12 distinct provinces). The employee's age category $(14 \leq$ age $\leq 20,20<$ age $\leq 25,25<$ age $\leq 35,35<$ age $\leq 45,45<$ age $\leq 55,55<$ age $\leq 60$; and $60<$ age $\leq 70$ ) and youngest child's age category (child aged $\leq 4$ years, $4<$ age child $\leq 12,12<$ age child $\leq 18$; and no children or children aged over 18) are determined based on ages in years and months as at February of the calendar year.

Job characteristics are measured in February of the given year, including type of contract (fixedterm contract, permanent contract and other contract), type of job (regular job, flexible job, payrolling

\footnotetext{
${ }^{4}$ This selection excludes about 0.02 per cent of observations on working hours and 0.2 per cent of observations on hourly wage. Results including these observations are similar, and available upon request.
} 
job, sheltered employment and internship) ${ }^{5}$; and full-time/part-time status ( $\geq 35$ weekly hours, $20 \leq$ hours $<35$, and $<20$ hours).

Firm characteristics are based on annual firm-level data measured in the third quarter of the preceding year, including firm size (0-19; 20-199; 200-499; and 500+ employees) and economic sector (5-digit Standard Industrial Classification (SBI) code). ${ }^{6}$ We use the 4-digit SBI code to classify firms as essential or non-essential. ${ }^{7}$ A limitation of the data is that we do not observe employees' occupations, and thus we are not able to assess the importance of occupation/industry-specific tasks and employees' ability to telecommute (Adams-Prassl et al., 2020b).

\subsection{Sample selection}

We create a monthly panel for individual employees who were employed in February of the year. Confirmed COVID-19 cases started spreading across the Netherlands from March 2020 onwards. The economic impact of COVID-19 is likely to follow a similar timeframe, as the lockdown imposed by the Dutch government also started in March 2020. We therefore select all jobs that existed in February of the given year, retaining the records for the main job of each employee, defined as the job with the highest working hours. The "treated" are individuals who were employed in February 2020. The controls are individuals who were employed in February 2019. The main job of the individual in February is followed over time from January to June of the given year.

The firm characteristics of this job are used to determine essential/non-essential worker status. For this reason, we exclude individual-year observations that have missing firm information from the sample. For employees who exit the main job of February, we follow the job with the highest working

\footnotetext{
${ }^{5}$ Flexible jobs include temporary and seconded workers. Payrolling jobs include employees who work at a client firm but are formally employed by an intermediary organisation. Sheltered employment includes jobs as defined in the Sheltered Employment Act, in Dutch: Wet Sociale Werkvoorziening, which provides work opportunities for people with a severe mental or physical disability.

${ }^{6}$ The Dutch Standard Industrial Classification, in Dutch: Standaard Bedrijfsindeling, is based on the European Union Nomenclature statistique des activités économiques dans la Communauté Européenne (NACE). The 4-digit SBI code is consistent with the 4-digit NACE Rev. 2 classification. See https://www.cbs.nl/en-gb/ourservices/methods/classifications/activiteiten/standard-industrial-classifications--dutch-sbi-2008-nace-and-isic-for more information.

${ }^{7}$ See Table A.1 in Appendix A for an overview of digit codes and essential/non-essential worker status, summary statistics on the proportion of essential workers, proportion of female workers, and sample size by one-digit economic sector.
} 
hours, if there is one. We also exclude individual-year observations of individuals younger than 14 years or older than 70 years in the month of February of the given year.

\section{Empirical strategy}

We compare the outcomes for the universe of jobs that existed in February 2020 to the universe of jobs that existed in February 2019. We follow individuals in these jobs for six months: two months before March and four months from March to June. We assess whether and how the impact of COVID-19 on individuals' labour market outcomes varies over the period after March. We use monthly information where $\tau$ represents the calendar month number. A monthly differences-in-differences specification is estimated:

$$
y_{i \tau c}=\sum_{\substack{\tau=1 \\ \tau \neq 2}}^{6} \gamma_{\tau} D Y_{c} \times D M_{\tau}+\sum_{\substack{\tau=1 \\ \tau \neq 2}}^{6} \beta_{\tau} D M_{\tau}+\delta D Y_{c}+\eta^{\prime} X_{i c}+\alpha_{i}+\varepsilon_{i \tau c}
$$

$i \in 1, \ldots, N ; \tau \in 1, \ldots, 6 ; c=2019,2020$

where (1) is a generic model for each of the outcome variables. The subscripts $i, \tau$ and $c$ refer to individual, calendar month and year, respectively. The vector $\gamma$ includes the parameters of interest, measuring the impact on the outcome variable by calendar month $\tau$ in 2020 relative to February 2020, compared with the outcomes in 2019 relative to February $2019 .{ }^{8}$ DY and $D M$ are $0-1$ indicator variables for calendar year and calendar month. Reference year is 2019 and reference month is February. Equation (1) is estimated for samples stratified by gender and by essential/non-essential worker status to study the effects of COVID-19.

The variables in vector $X$ are time constant within a year but may vary between 2019 and 2020 . $X$ includes dummy variables for individual characteristics (age, presence and age of children, and residential location at the provincial level), job characteristics (type of contract, type of job, and fulltime/part-time status), and firm characteristics (firm size, economic sector). Individual fixed effects are denoted by $\alpha$, and $\varepsilon$ represents an idiosyncratic error term.

\footnotetext{
${ }^{8}$ In a robustness check we show that the COVID-19 effects on employees are robust to using data of calendar year 2018 instead of 2019 (see Figure B.1 of Appendix B).
} 
To determine the extent that COVID-19 effects vary among employees with different individual and job characteristics such as gender, household composition and spousal employment, we apply a triple differences model:

$$
\begin{aligned}
y_{i c \tau}= & \alpha_{i}+\sum_{\substack{\tau=1 \\
\tau \neq 2}}^{6}\left[\left(\lambda_{\tau}{ }^{\prime} X_{i c}^{*}\right) \times D Y_{c} \times D M_{\tau}+\gamma_{\tau} D Y_{c} \times D M_{\tau}+\left(\kappa_{\tau}{ }^{\prime} X_{i c}^{*}\right) D M_{\tau}+\beta_{\tau} D M_{\tau}\right] \\
& +\left(\mu^{\prime} X_{i c}^{*}\right) \times D Y_{c}+\delta D Y_{c}+\eta^{\prime} X_{i c}+\varepsilon_{i c \tau}
\end{aligned}
$$

where $\lambda_{\tau}$ represents the parameters of interest, measuring differences in the COVID-19 impacts between specific groups of interest relative to a reference group. Vector $X^{*}$ now also contains time-constant variables gender and country of birth (Netherlands born versus foreign born) in addition to the timevarying covariates in $X$ outlined in the discussion of (1). Depending on stratification, variables are excluded from $X^{*}$. Equation (2) is estimated for samples stratified by gender and by essential/nonessential worker status to study the labour supply effects arising from the employee's household composition and spousal employment.

\section{Empirical results}

This section provides empirical evidence on the COVID-19 effects among Dutch employees. We first examine demand-side driven gender differences in the effects of COVID-19, showing the impact on labour market outcomes by gender and by essential/non-essential worker status. Then, we examine supply-side-driven heterogeneity in the impact of the COVID-19 shock, studying the importance of household composition defined by the individual's marital status, and the presence and age of children. In the final subsection, we assess, for partnered households with children aged below 12 years, whether the spousal employment status, characterised by their essential/non-essential worker status and fulltime/part-time status, affects the impact of COVID-19. 


\subsection{Gender differences in the COVID-19 effects on employment, working hours and hourly wages by essential/non-essential worker status}

Figure 1 shows the COVID-19 effects based on the differences-in-differences specification of equation (1), estimated separately for the four samples stratified by gender and by essential/non-essential worker status. COVID-19 effects are identified by comparing employees' outcomes in 2020 to employees' outcomes in 2019. The essential/non-essential worker status is based on the job-spell that existed in February of the given calendar year (see Table A.1 for an overview). The $y$-axis shows the impact on employment in percentage points (graph 1A) and on working hours and hourly wages in percentages (graphs 1B and 1C, respectively). The $x$-axis represents calendar month, ranging from 1 (January) to 6 (June). The reference year is 2019 and the reference month is 2 (February).

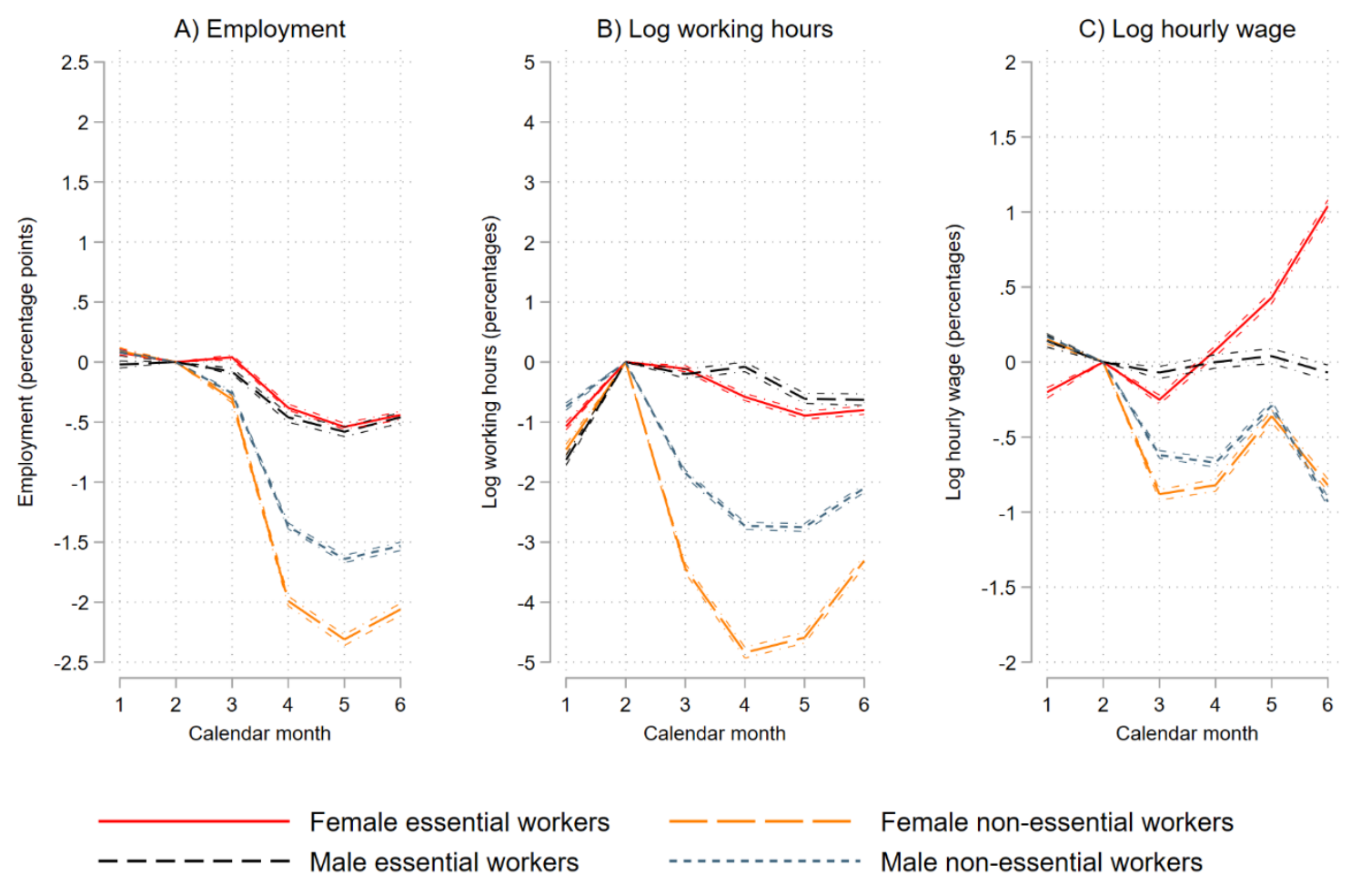

Figure 1 - COVID-19 Differences-in-Differences effects on employment, log hours worked and log hourly wages (Equation (1)); stratified by gender and by essential worker status (2020 compared to 2019)

Notes: Parameter estimates of the double interaction terms between year and calendar month. Each graph represents a different outcome variable and each line represents a single regression for a different sample stratified by gender and by essential worker status. Reference year is 2019 and reference calendar month is 2 (February). The $95 \%$ confidence intervals (the lighter dashed lines of the same colour) are computed based on standard errors clustered by individual. The number of individuals included in the employment graph is $2,147,503$ for female essential workers; 2,085,240 for female non-essential workers; 1,272,304 for male essential workers; and $3,261,782$ for male non-essential workers. For the other graphs, sample sizes are slightly smaller. 
Figure 1A shows that, relative to the three other subgroups, female non-essential workers experience the largest reduction in employment (relative to February in the same year), bottoming in May 2020 at about 2.3 percentage points. Male non-essential workers are 1.4 to 1.6 percentage points less likely to be employed throughout April to June 2020. Conversely, female essential workers and male essential workers experience only a minor reduction in employment of about 0.5 percentage points during April to June 2020.

The parallel trends identifying assumption appears to be violated in Figure 1B: In January 2020, relative to January 2019 , working hours are about 0.5 to 1.5 per cent lower for each of the four subgroups. This finding can be explained by the fact that 2020 is a leap year, increasing the working hours in February 2020 relative to January 2020 compared against the working hours in February 2019 relative to January 2019. For this reason, we interpret the impact on working hours relative to January instead of February. The 2020 leap year also affects the reported COVID-19 effects on hourly wages in graph 1C, but to a much lesser extent than the COVID-19 effects on working hours. Consistent with the leap year explanation, the parallel trends restriction holds for employment in graph 1A. Further supporting the parallel trends assumption is Figure B.1 of Appendix B, showing that the COVID-19 effects are robust to using data of year 2018 instead of 2019, indicating similar labour market dynamics in 2018 and 2019 across all months.

Figure 1B shows reduced working hours comparable to the lower employment over the period March to June 2020. On average, relative to January 2020, female non-essential workers experience a reduction of 3 to 3.5 per cent in working hours in the months of April and May. Male non-essential workers experience a reduction of 2 per cent in working hours. In contrast, both female and male essential workers experience hardly any reduction in working hours in the period from March 2020 onwards. ${ }^{9}$

\footnotetext{
${ }^{9}$ Figure B.2 provides results for the models on working hours and hourly wages, respectively, based on a specification in levels instead of in logs. This approach has the benefit of limiting selection into employment by including unemployed individuals in the sample, setting unemployed individuals' working hours and hourly wages to zero. The results in Figures B.2A and B.2B are consistent with those provided in Figures 1B and 1C, respectively.
} 
Figure $1 \mathrm{C}$ shows that the hourly wage of female essential workers increases by 0.5 to 1 per cent over the period April-June 2020, whereas female and male non-essential workers experience a decrease of about 0.5 to 1 per cent in hourly wages. This finding is important as it suggests a relatively rapid response to the COVID-19 pandemic from the demand side of the labour market, reducing wages for non-essential workers and increasing wages for essential workers, respectively. Wages increased especially for those sectors in which there are relatively many female essential workers, explained by a small decrease in working hours and a small increase in gross pay. ${ }^{10}$

Three key conclusions can be drawn. First, the results show that there is heterogeneity in COVID-19 effects on labour market outcomes by the employee's essential/non-essential worker status. The large difference between essential workers and non-essential workers highlights the importance of the demand side of the labour market, as the lockdown is limiting the economic activities of specific non-essential economic sectors, particularly accommodation and food service activities; culture, sports and recreation; and the renting and leasing of tangible goods, and other business support services (see Table A.2).

Second, the negative COVID-19 effects on labour market outcomes for non-essential workers started earlier. Non-essential workers experienced a reduction in employment, work hours and wages from March 2020 onwards, and the impact was most severe in April and May. For essential workers, the impact is much smaller and only started in April 2020. Essential workers' employment and working hours slightly increased again in June 2020, compared to May 2020, just after the national lockdown was removed.

Third, female essential workers and male essential workers have been affected similarly by the COVID-19 shock, whereas there is a notable difference between female non-essential workers and male non-essential workers. ${ }^{11}$ Specifically, relative to male non-essential workers, female non-essential workers faced larger reductions in employment and working hours. Importantly, however, the speed of

\footnotetext{
${ }^{10}$ The patterns in working hours and hourly wages could be due to changes in outcomes of individuals who remain in the same job-spell or due to labour turnover. In a follow-up analysis we find that the trends are driven by employees who remain in the same job-spell over the six months of each year. These results are available upon request.

${ }^{11}$ See Table A. 3 for sample means for individual characteristics in February 2020 by gender and by essential/nonessential worker status.
} 
re-employment is the same for women and men in June 2020 relative to May 2020. Notably, in February 2020, 52 per cent of the Dutch population of female employees are essential workers (see Table A.3), who are less affected by the COVID-19 shock in terms of labour market outcomes. In contrast, 72 per cent of male jobs are non-essential, who experience relatively worse outcomes. As a result, overall, women and men experienced similar COVID-19 effects on employment on average. ${ }^{12}$

\subsection{Role of household composition in the labour supply effects of the COVID-19 shock}

To establish the role of household composition in the impact of the COVID-19 shock on labour market outcomes by gender and by essential/non-essential worker status, Figures 2 to 5 provide estimates of the impact of the employee's household composition for each of these four groups separately. We estimate a triple-differences model, as outlined in equation (2), which includes triple and double interaction terms between calendar year, calendar month and all observables, ensuring we capture labour supply effects. Specifically, we estimate the triple-differences model separately for the four samples stratified by essential/non-essential worker status controlling for labour demand effects by including interaction terms between year, month and economic sector. ${ }^{13}$ The employee's household composition is defined in February of the relevant year based on the individual's marital status (single versus partnered) and the presence and age of the youngest child (four categories). The reference category contains employees who are single without children aged below 18 years. For readability, we have excluded the confidence intervals from the graphs.

If the emergency childcare policy is completely successful, essential workers with young children should experience similar COVID-19 effects on outcomes as essential workers who have no young children. In contrast, if the emergency childcare is relatively ineffective in facilitating parents' labour market participation during the Dutch national lockdown of mid-March until May 2020, we

\footnotetext{
${ }^{12}$ Based on the double-differences specification for samples stratified by gender only, the loss in employment is identical for women and men (see Figure B.3). Figure B.3 also shows that on average, women experience a 0.5 percentage point larger loss in working hours than men, but a 0.5 percentage point smaller loss in hourly wages.

${ }^{13}$ To provide an overview of the role of individual characteristics in COVID-19 effects over the period March to June 2020, we use a pre versus post triple-differences specification (aggregating the months before and after COVID-19 started) for samples stratified by essential/non-essential worker status and controlling for economic sector (see Table A.4 and Table A.5 for essential workers and non-essential workers, respectively).
} 
should see that households with young children experience worse outcomes during that period, both essential and non-essential workers.

A) Employment

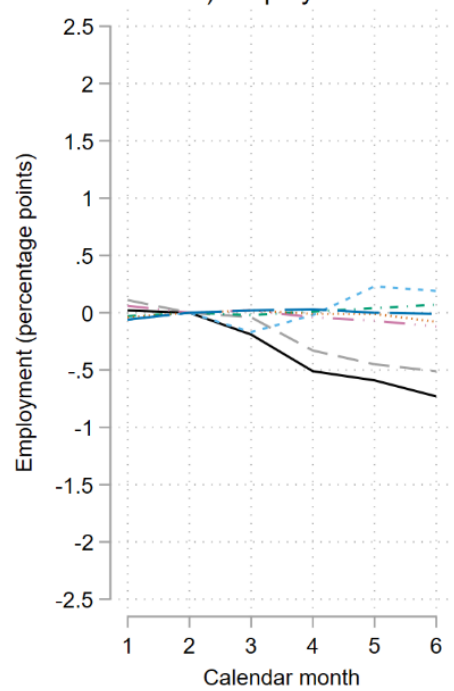

B) Log working hours

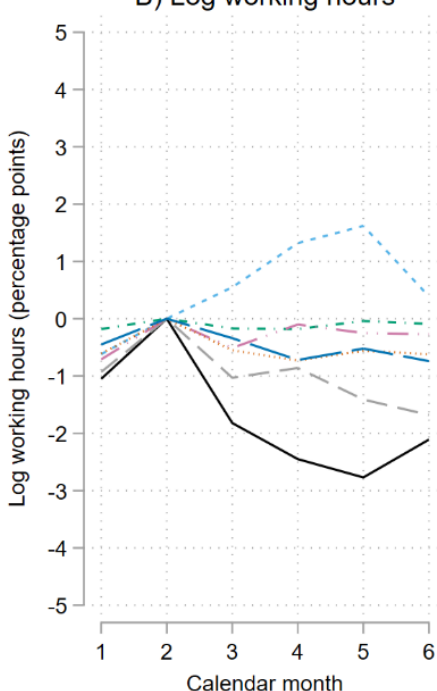

C) Log hourly wage

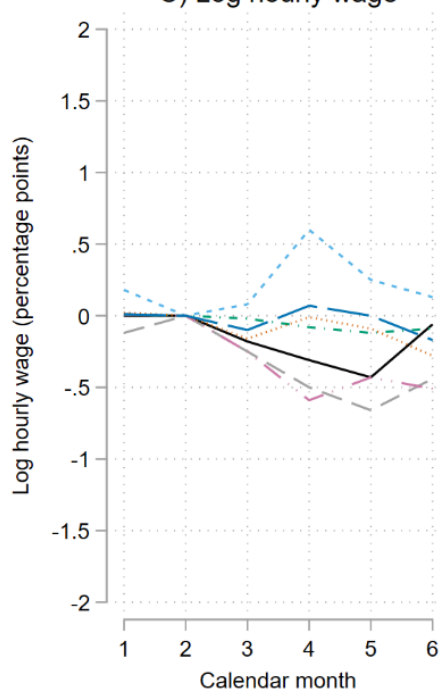

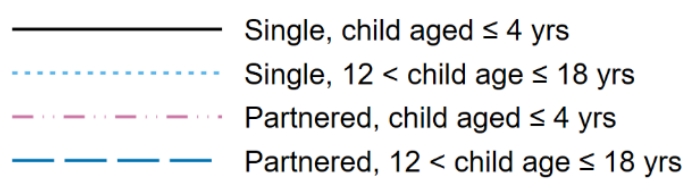

Partnered, no kids $\leq 18$ yrs

Partnered, $4<$ child age $\leq 12$ yrs

Figure 2 - COVID-19 triple differences effects on employment, log hours worked and log hourly wages based on the triple interaction term between household composition, year and month (Equation (2)); for female essential workers

Notes: Parameter estimates of the triple interaction terms between household composition, year and calendar month based on the sample of 2,147,503 female essential workers. Each graph represents a different outcome variable based on one single regression. The reference household is a single person without children, reference year is 2019 and reference calendar month is February. For clarity of the graphs, confidence intervals are excluded (but available upon request). Parameter estimates of the main variables, and the double interaction and triple interaction terms between year, calendar month and other observables are also estimated.

We show that the role of the presence and age of children in the COVID-19 impact is very small for partnered workers, irrespective of the employee's gender and essential/non-essential worker status (see figures 2 to 5). This evidence suggests that couples with young children have coped relatively well with the lockdown, and that this is not due to the emergency childcare, given similar impacts for essential and non-essential workers. In contrast, we observe that essential workers who are single and have a child aged below 4 years or between 4 and 12 years are particularly negatively affected by COVID-19 in terms of employment and working hours. Figure 2 shows that female essential workers, who are single and have children under 4 years, experience a 0.5 to 0.7 percentage points larger loss in employment 
and a 2 percentage point larger loss in working hours, relative to other female essential workers. Similarly, Figure 4 suggests that single male essential workers with young children also experience worse outcomes relative to other groups of male essential workers, although fewer triple interaction effects are statistically significant than for women. Although a small subpopulation, single parents are a substantial part of the Dutch labour force. Among essential workers, 4.4 per cent of women are single mothers of children aged below 12 years and 2.6 per cent of men are single fathers of children aged below 12 years (see Table A.3).

A) Employment

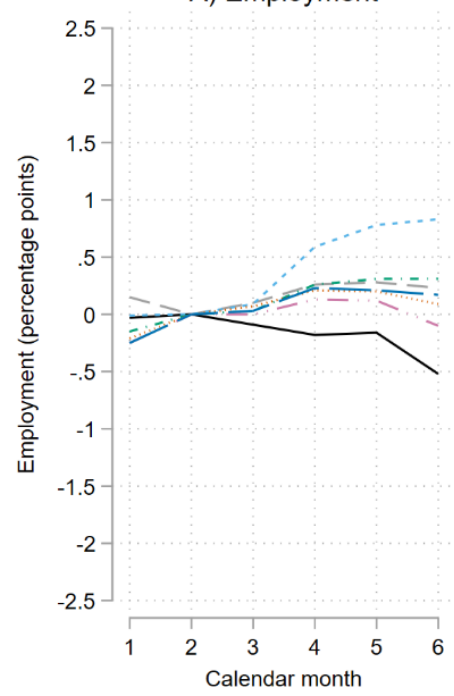

B) Log working hours

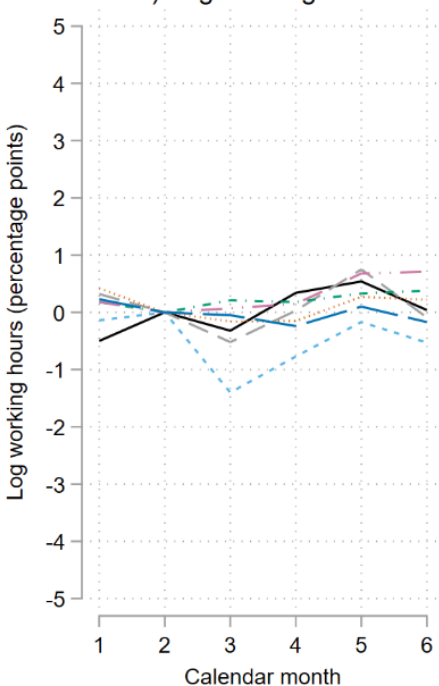

C) Log hourly wage

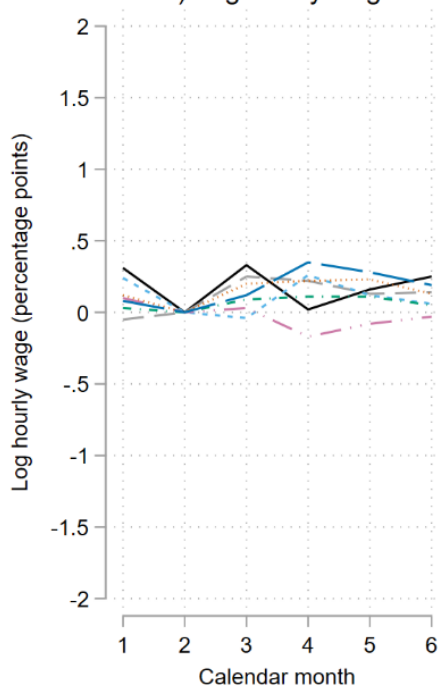

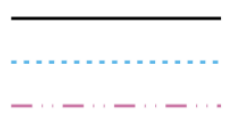

Single, child aged $\leq 4 \mathrm{yrs}$

Single, $12<$ child age $\leq 18 \mathrm{yrs}$

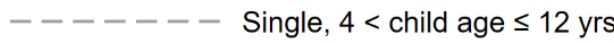

Partnered, child aged $\leq 4$ yrs

Partnered, no kids $\leq 18$ yrs

Partnered, $4<$ child age $\leq 12$ yrs

Figure 3 - COVID-19 triple differences effects on employment, log hours worked and log hourly wages based on the triple interaction term between household composition, year and month (Equation (2)); for female non-essential workers

Notes: Parameter estimates of the triple interaction terms between household composition, year and calendar month based on the sample of 2,085,240 female non-essential workers. The reference household is a single person without children, reference year is 2019 and reference calendar month is February. For other notes see Figure 2. 

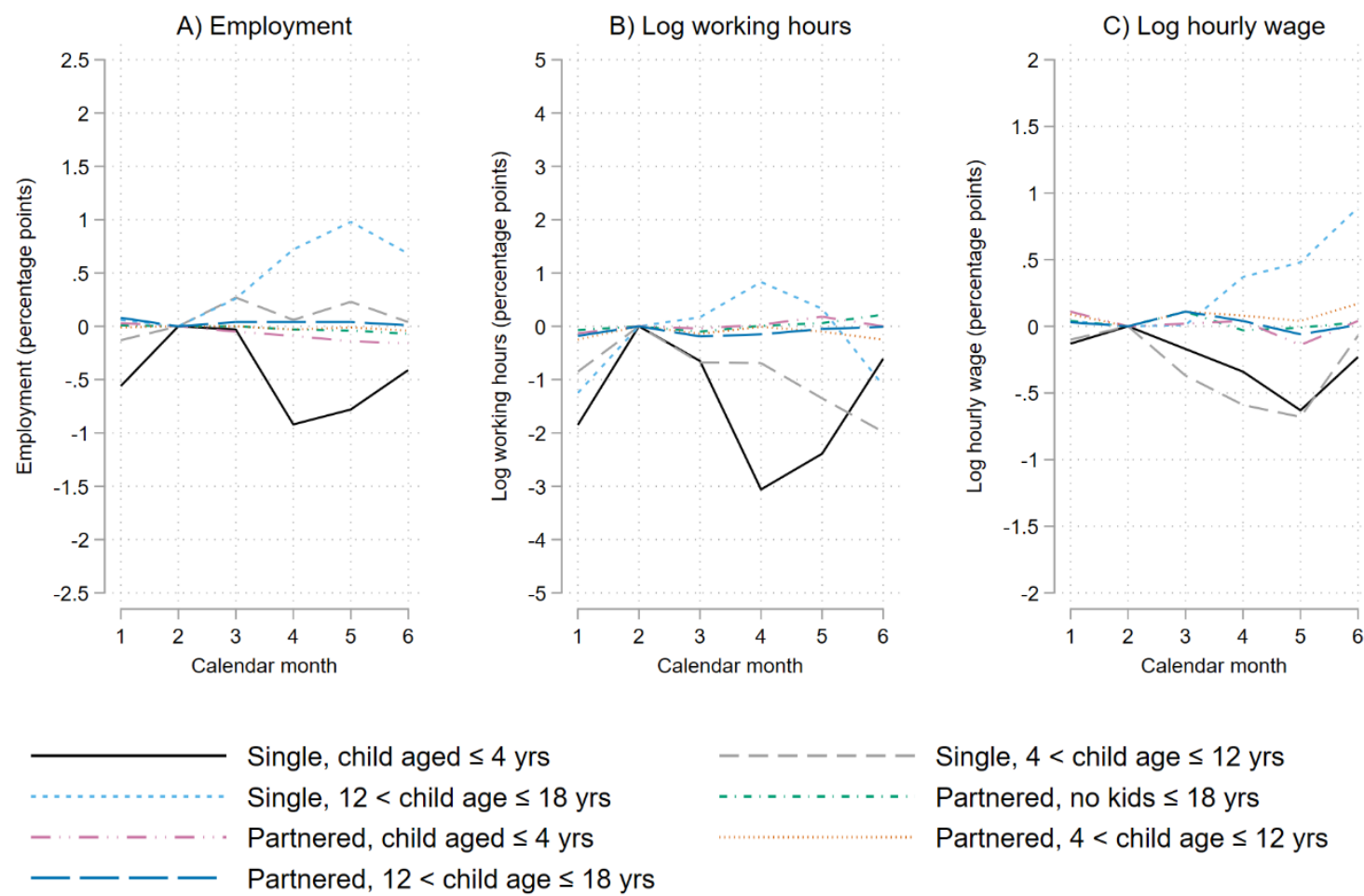

Figure 4 - COVID-19 triple differences effects on employment, log hours worked and log hourly wages based on the triple interaction term between household composition, year and month (Equation (2)); for male essential workers

Notes: Parameter estimates of the triple interaction terms between household composition, year and calendar month based on the sample of $1,272,304$ male essential workers. The reference household is a single person without children, reference year is 2019 and reference calendar month is February. For other notes see Figure 2.

Overall, for single parent essential workers with children aged below 12, the negative impacts on employment and working hours are largest in April and May. This evidence suggests that caring responsibilities at the time of a lockdown affects the labour supply decisions of single persons, who cannot share household responsibilities with a spouse, and the emergency childcare does not fully mitigate this problem. Conversely, there is little heterogeneity in COVID-19 effects for partnered employees, both women and men appear able to overcome the issue of balancing housework and paid work together. One interpretation of these findings is that couples, relative to single parents, may be more able to deal with the societal lockdown by sharing the burden of increased household responsibilities. 
A) Employment

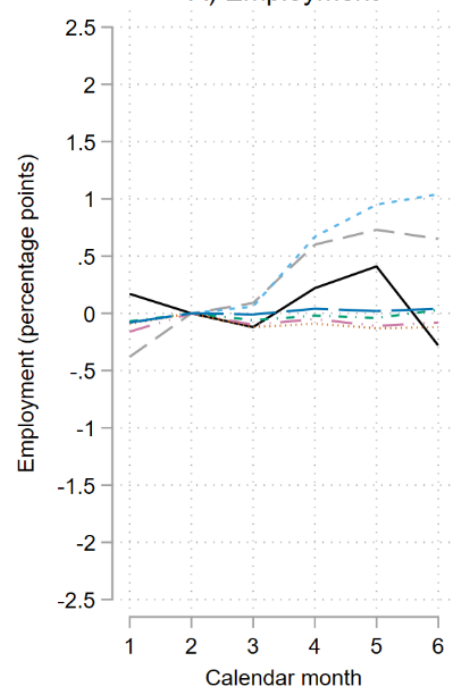

B) Log working hours

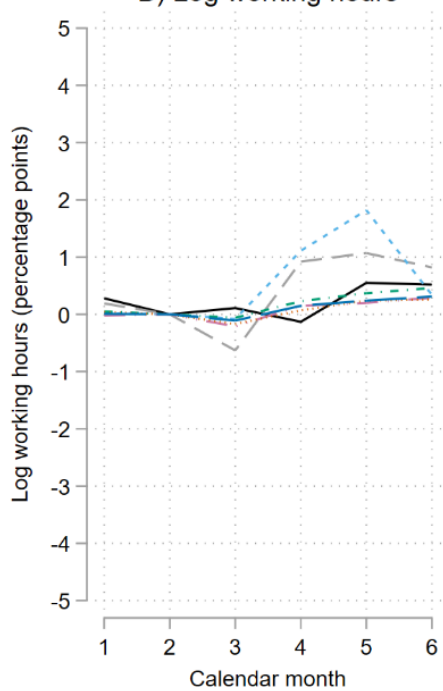

C) Log hourly wage

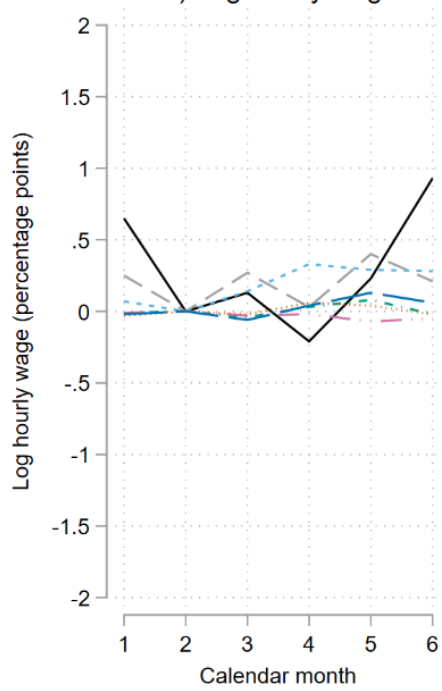

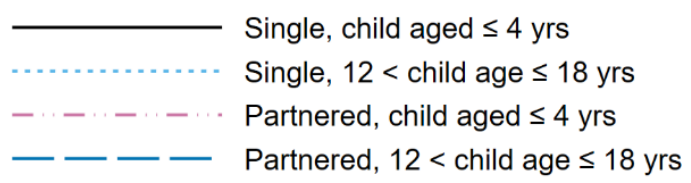

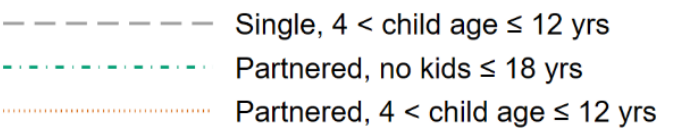

Figure 5 - COVID-19 triple differences effects on employment, log hours worked and log hourly wages based on the triple interaction term between household composition, year and month (Equation (2)); for male non-essential workers

Notes: Parameter estimates of the triple interaction terms between household composition, year and calendar month based on the sample of 3,261,782 male non-essential workers. The reference household is a single person without children, reference year is 2019 and reference calendar month is February. For other notes see Figure 2.

\subsection{Importance of the spousal employment status for the impact of COVID-19}

We study the importance of the spousal employment situation for the impact of COVID-19 on labour market outcomes for couples with children. We define the spousal employment situation based on the full-time/part-time status and essential/non-essential worker status in February of the relevant year. We estimate the triple differences model of equation (2) for a selective sample of full-time employees; that is, those who are partnered and have children aged below 12 years. Triple interaction effects are estimated for the four samples stratified by gender and by essential/non-essential worker status (Figures B.4 to B.7). The reference category consists of employees whose partners are full-time employed essential workers.

Figure B.4 of Appendix B shows the results for the sample of full-time employed female essential workers. Relative to women whose spouses are full-time essential workers, women who have 
spouses in different employment situations experience similar employment outcomes (see Graph B.4A). The evidence suggests little heterogeneity in the impact on hours worked based on the spouse's employment situation (Graph B.4B). Interestingly, relative to having a spouse who is a full-time essential worker, those who have a spouse with a different employment status face slightly reduced hourly wages (Graph B.4C). One explanation for this finding is the slightly larger reduction in working hours observed for those whose spouse is a full-time essential worker.

Overall, Figures B.4 to B.7 show that spousal employment circumstances are relatively unimportant for labour supply responses to the COVID-19 shock, irrespective of the individual's gender and essential/non-essential worker status. ${ }^{14}$ This is an important result, as it suggests that the COVID-19 shock at the peak of the lockdown in April and May 2020, was shared relatively equally in terms of labour market impacts by women and men in couple families with children under 12 .

\section{Discussion and conclusion}

The national societal lockdown in the Netherlands from mid-March until late May 2020 led to big challenges for households balancing home and work life. The compulsory closures of childcare and schools were likely to be a major disruption to the amount of time that can be dedicated to paid work, especially for mothers who often take primary responsibility for most of the unpaid work in the household. Using administrative microdata that cover the Dutch population of employees for the period until June 2020, we provide causal evidence on the gender differences in the COVID-19 effects on employment, paid working hours and hourly wages by essential/non-essential worker status and household composition.

Our conclusion is threefold. First, the larger impact on non-essential workers shows that the demand side of the labour market is particularly important in the COVID-19 effects on employees' labour market outcomes. We show that non-essential workers experienced negative COVID-19 effects on employment of 1.5 to 2.5 percentage points, on working hours of 2 to 3 per cent and on hourly wages

14 Using a sample of full-time employees who are partnered and have children aged below 4 years instead of 12 years, a similar conclusion is drawn. These results are available upon request. 
of 1 per cent, between April and June 2020. In general, essential workers experienced only minor negative effects; and for partnered men and women, outcomes were not more negative if young children are present in the household, irrespective of the spouse's employment situation.

Second, the COVID-19 shock did not seem to result in a widening of gender gaps in employment, working hours and hourly wages during the first six months of 2020. Female non-essential workers experienced slightly worse outcomes than male non-essential workers. However, 52 per cent of female employees are essential workers whereas for male employees this is only 28 per cent, and essential workers were less affected by the COVID-19 shock in terms of labour market outcomes. This explains why, on average, women and men experienced similar COVID-19 effects on employment.

Third, we observe that the part-time/full-time and essential/non-essential worker status of the spouse did not lead to different COVID-19 effects on labour market outcomes for full-time male and female essential and non-essential workers with children aged below 12. One interpretation of these findings is that the emergency childcare was not a very important mechanism to deal with the COVID19 shock in terms of balancing home and work life. Consistent with this notion, single parents with young children experienced relatively strong COVID-19 effects on labour market outcomes, including single parents who are essential workers and thus would have been eligible for the emergency childcare. This evidence suggests that the Dutch emergency childcare policy was not sufficient for single parents to balance family and paid work during the societal lockdown.

Taken together, the evidence suggests there are labour market institutions in place in the Netherlands, such as the Temporary Emergency Measure for the Preservation of Jobs and the generous provision of paid leave, that equally support female and male workers to remain employed while taking care of the family. In times of a strict but relatively short lockdown, as was the case in the Netherlands from mid-March until May 2020, the measures in place appear sufficient to prevent a widening of gender gaps in labour market outcomes due to the COVID-19 shock. 


\section{References}

Adams-Prassl, A., Boneva, T., Golin, M., \& Rauh, C. (2020a). Inequality in the impact of the coronavirus shock: Evidence from real time surveys. Journal of Public Economics, 189, 104245. https://doi.org/10.1016/j.jpubeco.2020.104245

Adams-Prassl, A., Boneva, T., Golin, M., \& Rauh, C. (2020b). Work that can be done from home: Evidence on variation within and across occupations and industries (IZA Discussion Paper No. 13374). Institute of Labor Economics.

Adda, J., Dustmann, C., \& Stevens, K. (2017). The career costs of children. Journal of Political Economy, 125(2), 293-337. https://doi.org/10.1086/690952

Alon, T., Doepke, M., Olmstead-Rumsey, J., \& Tertilt, M. (2020). The impact of COVID-19 on gender equality. Covid Economics, 4, 62-85. https://doi.org/10.3386/w26947

Andrew, A., Cattan, S., Dias, M. C., Farquharson, C., Kraftman, L., Krutikova, S., Phimister, A., \& Sevilla, A. (2020). The gendered division of paid and domestic work under lockdown (IZA Discussion Paper No. 13500). Institute of Labor Economics.

Bauernschuster, S., \& Schlotter, M. (2015). Public child care and mothers' labor supply-Evidence from two quasi-experiments. Journal of Public Economics, 123, 1-16. https://doi.org/10.1016/j.jpubeco.2014.12.013

Cortés, P., \& Pan, J. (2020). Children and the remaining gender gaps in the labor market (IZA Discussion Paper No. 13759). Institute of Labor Economics.

Del Boca, D., Oggero, N., Profeta, P., \& Rossi, M. (2020). Women's and men's work, housework and childcare, before and during COVID-19. Review of Economics of the Household, In Press. https://doi.org/10.1007/s11150-020-09502-1

Farré, L., Fawaz, Y., González, L., \& Graves, J. (2020). How the COVID-19 lockdown affected gender inequality in paid and unpaid work in Spain (IZA Discussion Paper No. 13434). Institute of Labor Economics.

Fuchs-Schündeln, N., Kuhn, M., \& Tertilt, M. (2020). The short-run macro implications of school and child-care closures (IZA Discussion Paper No. 13353). Institute of Labor Economics.

Hassink, W. H. J., Kalb, G., \& Meekes, J. (2020). The Dutch labour market early on in the COVID-19 outbreak: Regional coronavirus hotspots and the national lockdown (IZA Discussion Paper No. 13673). Institute of Labor Economics.

Havnes, T., \& Mogstad, M. (2011). Money for nothing? Universal child care and maternal employment. Journal of Public Economics, 95(11), 1455-1465. https://doi.org/10.1016/j.jpubeco.2011.05.016

Hupkau, C., \& Petrongolo, B. (2020). Work, care and gender during the COVID-19 crisis (IZA Discussion Paper No. 13762). Institute of Labor Economics. 
Kleven, H., Landais, C., \& Søgaard, J. E. (2019). Children and gender inequality: Evidence from Denmark. American Economic Journal: Applied Economics, 11(4), 181-209. https://doi.org/10.1257/app.20180010

Lewandowski, P., Lipowska, K., \& Magda, I. (2020). The gender dimension of occupational exposure to contagion in Europe (IZA Discussion Paper No. 13336). Institute of Labor Economics.

Meekes, J., \& Hassink, W. H. J. (2020). Fired and pregnant: Gender differences in job flexibility outcomes after job loss (IZA Discussion Paper No. 13779). Institute of Labor Economics.

Oreffice, S., \& Quintana-Domeque, C. (2020). Gender inequality in COVID-19 times: Evidence from UK prolific participants (IZA Discussion Paper No. 13463). Institute of Labor Economics.

Rijksinstituut voor Volksgezondheid en Milieu (2020). COVID-19 cumulatieve aantallen per gemeente. (in English: COVID-19 cumulative cases by municipality.) URL: https://data.rivm.nl/geonetwork/srv/dut/catalog.search\#/metadata/1c0fcd57-1102-4620-9cfa441e93ea5604?tab=general accessed on 21-08-2020.

Sevilla, A., \& Smith, S. (2020). Baby steps: The gender division of childcare during the COVID-19 pandemic. Oxford Review of Economic Policy, 36(S1), S169-S186. https://doi.org/10.1093/oxrep/graa027

Von Gaudecker, H.-M., Holler, R., Janys, L., Sifinger, B., \& Zimpelmann, C. (2020). Labour supply during lockdown and a "New Normal": The case of the Netherlands (IZA Discussion Paper No. 13623). Institute of Labor Economics. 


\section{Appendix A: Supplementary tables}

Table A.1

Proportion of essential workers and female workers by economic sector

\begin{tabular}{|c|c|c|c|c|c|}
\hline One-digit SBI sector: & $\begin{array}{c}\text { Essential or } \\
\text { non-essential } \\
\text { sector }\end{array}$ & $\begin{array}{c}\text { Proportion } \\
\text { of essential } \\
\text { workers }\end{array}$ & $\begin{array}{c}\text { Proportion } \\
\text { of female } \\
\text { workers }\end{array}$ & $\begin{array}{c}\text { Sample size } \\
\text { in February } \\
2020 \\
\end{array}$ & $\begin{array}{l}\text { 2- or higher-digit } \\
\text { SBI defined as } \\
\text { essential worker }\end{array}$ \\
\hline A Agriculture, forestry and fishing & Mixed & 0.98 & 0.32 & 83,629 & $01 ; 03$ \\
\hline B Mining and quarrying & Mixed & 0.36 & 0.16 & 7,793 & 06 \\
\hline C Manufacturing & Mixed & 0.20 & 0.22 & 734,417 & $\begin{array}{l}10 ; 1910 ; 19201 ; \\
21 ; 325\end{array}$ \\
\hline $\begin{array}{l}\text { D Electricity, gas, steam and air } \\
\text { conditioning supply }\end{array}$ & Mixed & 1.00 & 0.24 & 26,740 & 351 \\
\hline $\begin{array}{l}\text { E Water supply; sewerage, waste } \\
\text { management and remediation activities }\end{array}$ & Essential & 1.00 & 0.18 & 35,169 & $36 ; 37 ; 38 ; 39$ \\
\hline F Construction & $\begin{array}{c}\text { Non- } \\
\text { essential }\end{array}$ & 0.00 & 0.12 & 317,590 & \\
\hline $\begin{array}{l}\text { G Wholesale and retail trade; repair of } \\
\text { motor vehicles and cycles }\end{array}$ & Mixed & 0.29 & 0.46 & $1,328,723$ & $\begin{array}{l}4711 ; 473 ; 4773 ; \\
4774\end{array}$ \\
\hline $\mathrm{H}$ Transportation and storage & Mixed & 0.44 & 0.25 & 359,454 & $\begin{array}{l}491 ; 492 ; 4931 \\
494 ; 495 ; 51\end{array}$ \\
\hline $\begin{array}{l}\text { I Accommodation and food service } \\
\text { activities }\end{array}$ & $\begin{array}{l}\text { Non- } \\
\text { essential }\end{array}$ & 0.00 & 0.51 & 383,160 & \\
\hline $\mathrm{J}$ Information and communication & Mixed & 0.08 & 0.28 & 275,873 & $6110 ; 6120 ; 6130$ \\
\hline K Financial institutions & $\begin{array}{c}\text { Non- } \\
\text { essential }\end{array}$ & 0.00 & 0.40 & 248,145 & \\
\hline $\begin{array}{l}\text { L Rental, buying and selling of real } \\
\text { estate }\end{array}$ & $\begin{array}{c}\text { Non- } \\
\text { essential }\end{array}$ & 0.00 & 0.50 & 64,131 & \\
\hline $\begin{array}{l}\text { M Consultancy, research and other } \\
\text { specialised business services }\end{array}$ & $\begin{array}{l}\text { Non- } \\
\text { essential }\end{array}$ & 0.00 & 0.41 & 504,569 & \\
\hline $\begin{array}{l}\text { N Renting and leasing of tangible goods } \\
\text { and other business support services }\end{array}$ & Mixed & 0.04 & 0.44 & 814,467 & 80 \\
\hline $\begin{array}{l}\text { O Public administration, public services } \\
\text { and compulsory social security }\end{array}$ & Essential & 1.00 & 0.44 & 508,928 & 84 \\
\hline P Education & Mixed & 0.69 & 0.66 & 512,199 & $852 ; 853$ \\
\hline $\begin{array}{l}\text { Q Human health and social work } \\
\text { activities }\end{array}$ & Essential & 1.00 & 0.84 & $1,318,295$ & $86 ; 87 ; 88$ \\
\hline R Culture, sports and recreation & $\begin{array}{l}\text { Non- } \\
\text { essential }\end{array}$ & 0.00 & 0.53 & 116,714 & \\
\hline S Other service activities & Mixed & 0.06 & 0.66 & 123,689 & 9603 \\
\hline $\begin{array}{l}\text { T Activities of households as employers; } \\
\text { undifferentiated goods and service- } \\
\text { producing activities of households for } \\
\text { own use }\end{array}$ & $\begin{array}{c}\text { Non- } \\
\text { essential }\end{array}$ & 0.00 & NA & 27 & \\
\hline $\begin{array}{l}\text { U Extraterritorial organisations and } \\
\text { bodies }\end{array}$ & Essential & 1.00 & 0.54 & 1,103 & 99 \\
\hline \multicolumn{6}{|c|}{$\begin{array}{l}\text { Notes: See the government announcement on childcare for children of people working in crucial sectors on } \\
\text { https://www.government.nl/topics/coronavirus-covid-19/documents/publications/2020/03/20/childcare-for-children-of-people-working- }\end{array}$} \\
\hline
\end{tabular}


Table A.2

Proportion of workers who are employed in June 2020, by 1-digit economic sector

\begin{tabular}{|c|c|c|c|c|}
\hline \multirow[b]{2}{*}{ One-digit SBI sector: } & \multicolumn{2}{|c|}{ Women } & \multicolumn{2}{|c|}{ Men } \\
\hline & $\begin{array}{c}\text { Proportion of } \\
\text { essential workers } \\
\text { who are employed } \\
\text { in June } 2020\end{array}$ & $\begin{array}{c}\text { Proportion of non- } \\
\text { essential workers } \\
\text { who are employed in } \\
\text { June } 2020\end{array}$ & $\begin{array}{c}\text { Proportion of } \\
\text { essential workers } \\
\text { who are employed } \\
\text { in June } 2020\end{array}$ & $\begin{array}{c}\text { Proportion of non- } \\
\text { essential workers } \\
\text { who are employed } \\
\text { in June } 2020\end{array}$ \\
\hline $\begin{array}{l}\text { A Agriculture, forestry and } \\
\text { fishing }\end{array}$ & 0.9449 & 0.9767 & 0.9586 & 0.9732 \\
\hline B Mining and quarrying & 0.9613 & 0.9753 & 0.9816 & 0.9733 \\
\hline C Manufacturing & 0.9599 & 0.9702 & 0.9729 & 0.9744 \\
\hline $\begin{array}{l}\text { D Electricity, gas, steam and air } \\
\text { conditioning supply }\end{array}$ & 0.9755 & $\begin{array}{l}\text { Suppressed for } \\
\text { confidentiality } \\
\text { reasons (small } \\
\text { sample size) }\end{array}$ & 0.9811 & $\begin{array}{l}\text { Suppressed for } \\
\text { confidentiality } \\
\text { reasons (small } \\
\text { sample size) }\end{array}$ \\
\hline $\begin{array}{l}\text { E Water supply; sewerage, } \\
\text { waste management and } \\
\text { remediation activities }\end{array}$ & 0.9765 & Not applicable & 0.9776 & Not applicable \\
\hline F Construction & Not applicable & 0.9710 & Not applicable & 0.9759 \\
\hline $\begin{array}{l}\text { G Wholesale and retail trade; } \\
\text { repair of motor vehicles and } \\
\text { cycles }\end{array}$ & 0.9439 & 0.9377 & 0.9347 & 0.9548 \\
\hline $\mathrm{H}$ Transportation and storage & 0.9677 & 0.9541 & 0.9705 & 0.9509 \\
\hline $\begin{array}{l}\text { I Accommodation and food } \\
\text { service activities }\end{array}$ & Not applicable & 0.8785 & Not applicable & 0.8689 \\
\hline $\begin{array}{l}\mathrm{J} \text { Information and } \\
\text { communication }\end{array}$ & 0.9710 & 0.9481 & 0.9748 & 0.9617 \\
\hline K Financial institutions & Not applicable & 0.9731 & Not applicable & 0.9725 \\
\hline $\begin{array}{l}\text { L Rental, buying and selling of } \\
\text { real estate }\end{array}$ & Not applicable & 0.9605 & Not applicable & 0.9626 \\
\hline $\begin{array}{l}\text { M Consultancy, research and } \\
\text { other specialised business } \\
\text { services }\end{array}$ & Not applicable & 0.9514 & Not applicable & 0.9567 \\
\hline $\begin{array}{l}\text { N Renting and leasing of } \\
\text { tangible goods and other } \\
\text { business support services }\end{array}$ & 0.9438 & 0.8815 & 0.9472 & 0.8775 \\
\hline $\begin{array}{l}\text { O Public administration, public } \\
\text { services and compulsory social } \\
\text { security }\end{array}$ & 0.9850 & Not applicable & 0.9782 & Not applicable \\
\hline P Education & 0.9850 & 0.9415 & 0.9814 & 0.9350 \\
\hline $\begin{array}{l}\text { Q Human health and social } \\
\text { work activities }\end{array}$ & 0.9707 & Not applicable & 0.9657 & Not applicable \\
\hline R Culture, sports and recreation & Not applicable & 0.9108 & Not applicable & 0.9056 \\
\hline S Other service activities & 0.9354 & 0.9436 & 0.9308 & 0.9431 \\
\hline $\begin{array}{l}\text { T Activities of households as } \\
\text { employers; undifferentiated } \\
\text { goods and service- producing } \\
\text { activities of households for own } \\
\text { use }\end{array}$ & Not applicable & $\begin{array}{l}\text { Suppressed for } \\
\text { confidentiality } \\
\text { reasons (small } \\
\text { sample size) }\end{array}$ & Not applicable & $\begin{array}{l}\text { Suppressed for } \\
\text { confidentiality } \\
\text { reasons (small } \\
\text { sample size) }\end{array}$ \\
\hline $\begin{array}{l}\text { U Extraterritorial organisations } \\
\text { and bodies }\end{array}$ & 0.9613 & Not applicable & 0.9764 & Not applicable \\
\hline
\end{tabular}


Table A.3

Sample means in February 2020 (proportions unless otherwise noted)

\begin{tabular}{|c|c|c|c|c|}
\hline & \multicolumn{2}{|c|}{ Women } & \multicolumn{2}{|c|}{ Men } \\
\hline & Essential & Non-essential & Essential & Non-essential \\
\hline Employment & 1 & 1 & 1 & 1 \\
\hline Work hours $(\log )$ & 4.5575 & 4.5263 & 4.7921 & 4.8657 \\
\hline Work hours (monthly hours) & 107.50 & 110.80 & 138.33 & 145.52 \\
\hline Hourly wage $(\log )$ & 2.8261 & 2.6618 & 2.9015 & 2.8822 \\
\hline Hourly wage (euro per month) & 19.02 & 16.50 & 21.52 & 21.19 \\
\hline Gross wage (log) & 7.3775 & 7.1862 & 7.6817 & 7.7474 \\
\hline Gross wage (euro per month) & 2180.65 & 2009.61 & 3187.09 & 3269.10 \\
\hline Female & 1 & 1 & 0 & 0 \\
\hline \multicolumn{5}{|l|}{ Age } \\
\hline $14 \leq$ age $\leq 20$ & 0.0801 & 0.0882 & 0.1103 & 0.0655 \\
\hline $20<$ age $\leq 25$ & 0.0824 & 0.1220 & 0.0724 & 0.1006 \\
\hline $25<$ age $\leq 35$ & 0.2059 & 0.2359 & 0.1746 & 0.2254 \\
\hline $35<$ age $\leq 45$ & 0.1939 & 0.1914 & 0.1722 & 0.1941 \\
\hline $45<$ age $\leq 55$ & 0.2254 & 0.2158 & 0.2124 & 0.2193 \\
\hline $55<$ age $\leq 60$ & 0.1162 & 0.0825 & 0.1252 & 0.0994 \\
\hline $60<$ age $\leq 70$ & 0.0961 & 0.0642 & 0.1329 & 0.0956 \\
\hline Born in the Netherlands & 0.9137 & 0.8179 & 0.9105 & 0.8488 \\
\hline \multicolumn{5}{|l|}{ Household composition } \\
\hline Single and no kids $\leq 18$ years & 0.2172 & 0.2695 & 0.2488 & 0.3048 \\
\hline Single, child aged $\leq 4$ years & 0.0088 & 0.0086 & 0.0034 & 0.0028 \\
\hline Single, $4<$ child age $\leq 12$ & 0.0350 & 0.0345 & 0.0224 & 0.0151 \\
\hline Single, $12<$ child age $\leq 18$ & 0.0776 & 0.0811 & 0.0868 & 0.0544 \\
\hline Partnered, no kids $\leq 18$ years & 0.3476 & 0.3383 & 0.3584 & 0.3366 \\
\hline Partnered, child aged $\leq 4$ years & 0.1055 & 0.0861 & 0.0924 & 0.0967 \\
\hline Partnered, $4<$ child age $\leq 12$ & 0.1223 & 0.1061 & 0.1084 & 0.1122 \\
\hline Partnered, $12<$ child age $\leq 18$ & 0.0860 & 0.0757 & 0.0795 & 0.0774 \\
\hline Partnered & 0.6614 & 0.6062 & 0.6387 & 0.6228 \\
\hline \multicolumn{5}{|l|}{ Type of contract } \\
\hline Permanent contract & 0.7338 & 0.6023 & 0.7271 & 0.6510 \\
\hline Fixed contract & 0.2625 & 0.3800 & 0.2574 & 0.2938 \\
\hline Other contract (identical to "Other job") & 0.0037 & 0.0177 & 0.0155 & 0.0552 \\
\hline \multicolumn{5}{|l|}{ Type of job } \\
\hline Regular job & 0.8802 & 0.7338 & 0.8717 & 0.7588 \\
\hline Flexible job & 0.0893 & 0.2064 & 0.0955 & 0.1478 \\
\hline Payrolling job & 0.0001 & 0.0148 & 0.0000 & 0.0086 \\
\hline Other job (identical to "Other contract") & 0.0037 & 0.0177 & 0.0155 & 0.0552 \\
\hline Intern job & 0.0263 & 0.0151 & 0.0153 & 0.0136 \\
\hline Sheltered employment & 0.0004 & 0.0122 & 0.0019 & 0.0159 \\
\hline \multicolumn{5}{|l|}{ Full-time/part-time status } \\
\hline$\geq 35$ work hours a week & 0.1773 & 0.3102 & 0.6461 & 0.7386 \\
\hline $20 \leq$ hours a week $<35$ & 0.5704 & 0.4112 & 0.2071 & 0.1424 \\
\hline Hours a week $<20$ & 0.2522 & 0.2786 & 0.1468 & 0.1190 \\
\hline Number of individuals & $1,954,628$ & $1,783,096$ & $1,117,720$ & $2,909,371$ \\
\hline
\end{tabular}

Notes: Sample means for individual characteristics are provided for calendar month 2 (February) in 2020 for samples stratified by gender and by essential worker status. Summary statistics are not provided for all variables in the modelling; residential location, firm size and economic sector are included in the model, but not in this table. 
Table A.4

COVID-19 triple differences effects on employment, log hours worked and log hourly wages based on a sample of essential workers (Equation (2))

\begin{tabular}{|c|c|c|c|}
\hline & $\begin{array}{c}\text { Employment } \\
(=1) \\
(1)\end{array}$ & $\begin{array}{c}\text { Working hours } \\
\text { (log) } \\
\text { (2) }\end{array}$ & $\begin{array}{l}\text { Hourly wage } \\
\text { (log) } \\
\text { (3) }\end{array}$ \\
\hline \multicolumn{4}{|c|}{ Triple interaction term: $D Y \times P O S T \times$} \\
\hline FEMALE: relative to male & $\begin{array}{c}0.0007 * * \\
(0.0003)\end{array}$ & $\begin{array}{c}-0.0023 * * * \\
(0.0006)\end{array}$ & $\begin{array}{c}-0.0007 * * \\
(0.0003)\end{array}$ \\
\hline \multicolumn{4}{|l|}{ AGE: relative to $35<$ age $\leq 45$} \\
\hline $14 \leq$ age $\leq 20$ & $\begin{array}{c}0.0102 * * * \\
(0.0009)\end{array}$ & $\begin{array}{c}0.0456 * * * \\
(0.0020)\end{array}$ & $\begin{array}{c}0.0172 * * * \\
(0.0013)\end{array}$ \\
\hline $20<$ age $\leq 25$ & $\begin{array}{c}0.0030 * * * \\
(0.0006)\end{array}$ & $\begin{array}{c}0.0057 * * * \\
(0.0012)\end{array}$ & $\begin{array}{l}-0.0001 \\
(0.0007)\end{array}$ \\
\hline $25<$ age $\leq 35$ & $\begin{array}{l}0.0006 * * \\
(0.0003)\end{array}$ & $\begin{array}{c}0.0014 * * * \\
(0.0005)\end{array}$ & $\begin{array}{c}0.0003 \\
(0.0003)\end{array}$ \\
\hline $45<$ age $\leq 55$ & $\begin{array}{c}-0.0006^{* *} \\
(0.0003)\end{array}$ & $\begin{array}{c}-0.0015^{* * *} \\
(0.0004)\end{array}$ & $\begin{array}{c}0.0004 \\
(0.0002)\end{array}$ \\
\hline $55<$ age $\leq 60$ & $\begin{array}{l}-0.0005 \\
(0.0003)\end{array}$ & $\begin{array}{c}-0.0011 * * \\
(0.0005)\end{array}$ & $\begin{array}{c}-0.0008 * * \\
(0.0003)\end{array}$ \\
\hline $60<$ age $\leq 70$ & $\begin{array}{c}-0.0137 * * * \\
\quad(0.0004)\end{array}$ & $\begin{array}{l}-0.0030 * * * \\
\quad(0.0006)\end{array}$ & $\begin{array}{l}-0.0028 * * * \\
\quad(0.0004)\end{array}$ \\
\hline $\begin{array}{l}\text { FOREIGN BORN: relative to born in } \\
\text { Netherlands }\end{array}$ & $\begin{array}{c}-0.0024 * * * \\
(0.0004)\end{array}$ & $\begin{array}{c}-0.0036 * * * \\
(0.0007)\end{array}$ & $\begin{array}{c}-0.0016 * * * \\
(0.0004)\end{array}$ \\
\hline \multicolumn{4}{|c|}{$\begin{array}{l}\text { HOUSEHOLD COMPOSITION: relative to } \\
\text { single and no kids } \leq 18 \text { years }\end{array}$} \\
\hline Single, child aged $\leq 4$ years & $\begin{array}{c}-0.0052 * * * \\
(0.0019)\end{array}$ & $\begin{array}{c}-0.0162 * * * \\
(0.0037)\end{array}$ & $\begin{array}{l}-0.0024 \\
(0.0018)\end{array}$ \\
\hline Single, $4<$ child age $\leq 12$ & $\begin{array}{c}-0.0028 * * * \\
(0.0009)\end{array}$ & $\begin{array}{c}-0.0080 * * * \\
(0.0019)\end{array}$ & $\begin{array}{c}-0.0037 * * * \\
(0.0010)\end{array}$ \\
\hline Single, $12<$ child age $\leq 18$ & $\begin{array}{l}0.0022 * * * \\
(0.0007)\end{array}$ & $\begin{array}{l}0.0107 * * * \\
(0.0016)\end{array}$ & $\begin{array}{c}0.0026^{* * *} \\
(0.0010)\end{array}$ \\
\hline Partnered, no kids $\leq 18$ years & $\begin{array}{c}0.0001 \\
(0.0003)\end{array}$ & $\begin{array}{l}-0.0003 \\
(0.0005)\end{array}$ & $\begin{array}{l}-0.0004 \\
(0.0003)\end{array}$ \\
\hline Partnered, child aged $\leq 4$ years & $\begin{array}{c}-0.0010 * * * \\
(0.0004)\end{array}$ & $\begin{array}{c}0.0005 \\
(0.0006)\end{array}$ & $\begin{array}{c}-0.0027 * * * \\
(0.0004)\end{array}$ \\
\hline Partnered, $4<$ child age $\leq 12$ & $\begin{array}{c}0.0000 \\
(0.0003)\end{array}$ & $\begin{array}{c}-0.0023 * * * \\
(0.0006)\end{array}$ & $\begin{array}{l}-0.0003 \\
(0.0004)\end{array}$ \\
\hline Partnered, $12<$ child age $\leq 18$ & $\begin{array}{c}0.0002 \\
(0.0003)\end{array}$ & $\begin{array}{c}-0.0028 * * * \\
(0.0006)\end{array}$ & $\begin{array}{c}0.0000 \\
(0.0004)\end{array}$ \\
\hline \multicolumn{4}{|c|}{ CONTRACT: relative to permanent contract } \\
\hline Fixed contract & $\begin{array}{c}-0.0060 * * * \\
(0.0003)\end{array}$ & $\begin{array}{c}-0.0086 * * * \\
(0.0006)\end{array}$ & $\begin{array}{l}-0.0003 \\
(0.0003)\end{array}$ \\
\hline Other contract & $\begin{array}{c}-0.0035 * * * \\
(0.0010)\end{array}$ & $\begin{array}{c}0.0025 * * \\
(0.0012)\end{array}$ & $\begin{array}{c}-0.0076^{* * *} \\
(0.0011)\end{array}$ \\
\hline \multicolumn{4}{|l|}{ TYPE OF JOB: relative to regular job } \\
\hline Flexible job & $\begin{array}{c}-0.0193 * * * \\
(0.0007)\end{array}$ & $\begin{array}{c}0.0131 * * * \\
(0.0016)\end{array}$ & $\begin{array}{c}-0.0096 * * * \\
(0.0006)\end{array}$ \\
\hline Payrolling job & $\begin{array}{c}-0.0091 \\
(0.0371)\end{array}$ & $\begin{array}{c}-0.4341 * \\
(0.2308)\end{array}$ & $\begin{array}{c}0.0096 \\
(0.0414)\end{array}$ \\
\hline Intern & $\begin{array}{c}-0.0132 * * * \\
(0.0015)\end{array}$ & $\begin{array}{c}-0.0534 * * * \\
(0.0034)\end{array}$ & $\begin{array}{c}-0.0584 * * * \\
(0.0037)\end{array}$ \\
\hline Sheltered employment & $\begin{array}{c}-0.0065^{* * *} \\
(0.0020)\end{array}$ & $\begin{array}{c}-0.0066^{* * *} * \\
(0.0015)\end{array}$ & $\begin{array}{c}-0.0003 \\
(0.0011) \\
\end{array}$ \\
\hline
\end{tabular}




\begin{tabular}{|c|c|c|c|}
\hline & $\begin{array}{l}\text { Employment } \\
\qquad(=1) \\
(1)\end{array}$ & $\begin{array}{l}\text { Working hours } \\
(\log ) \\
(2)\end{array}$ & $\begin{array}{l}\text { Hourly wage } \\
\text { (log) } \\
\text { (3) }\end{array}$ \\
\hline \multicolumn{4}{|c|}{$\begin{array}{l}\text { FT/PT STATUS: relative to } \geq 35 \text { work hours a } \\
\text { week }\end{array}$} \\
\hline $20 \leq$ hours a week $<35$ & $\begin{array}{c}-0.0010 * * * \\
(0.0003)\end{array}$ & $\begin{array}{c}0.0017 * * * \\
(0.0005)\end{array}$ & $\begin{array}{c}0.0061 * * * \\
(0.0003)\end{array}$ \\
\hline Hours a week $<20$ & $\begin{array}{c}-0.0098 * * * \\
(0.0004)\end{array}$ & $\begin{array}{l}0.0070 * * * \\
(0.0009)\end{array}$ & $\begin{array}{c}0.0041 * * * \\
(0.0006)\end{array}$ \\
\hline Number of individuals & $3,419,807$ & $3,419,800$ & $3,413,661$ \\
\hline Number of observations & $36,402,474$ & $35,844,688$ & $35,718,605$ \\
\hline \multicolumn{4}{|c|}{$\begin{array}{l}\text { Notes: Parameter estimates of the triple interaction terms between year 2020, POST and each of the covariates are reported } \\
\text { based on the sample of essential workers. POST is used instead of DM (see equation (2)), where POST equals one for calendar } \\
\text { months } 3 \text { (March) to } 6 \text { (June) and zero for months } 1 \text { (January) and } 2 \text { (February). Each column represents a single regression for } \\
\text { a different outcome variable. Reference year is } 2019 \text { and reference POST is months } 1 \text { to } 2 \text { (January to February). Reference } \\
\text { category of each covariate is reported in the table. Main effects and two-way interaction effects are not reported. Main, two-way } \\
\text { and three-way interaction terms are also included for residential location, firm size and economic sector. These results are } \\
\text { available from the authors upon request. Standard errors, clustered by individual, are in parentheses. ***,**, *, correspond to } \\
\text { the significance level of } 1 \%, 5 \%, 10 \% \text {, respectively. }\end{array}$} \\
\hline
\end{tabular}


Table A.5

COVID-19 triple differences effects on employment, log hours worked and log hourly wages based on a sample of non-essential workers (Equation (2))

$\begin{array}{ccc}\begin{array}{c}\text { Employment } \\ (=1)\end{array} & \text { Working hours } & \text { Hourly wage } \\ (1) & (\log ) & (\log ) \\ & (2) & (3)\end{array}$

\begin{tabular}{|c|c|c|c|}
\hline \multicolumn{4}{|c|}{ Triple interaction term: $D Y \times P O S T \times$} \\
\hline FEMALE: relative to male & $\begin{array}{l}0.0021^{* * *} \\
(0.0003)\end{array}$ & $\begin{array}{l}-0.0002 \\
(0.0005)\end{array}$ & $\begin{array}{c}0.0009 * * * \\
(0.0002)\end{array}$ \\
\hline \multicolumn{4}{|l|}{ AGE: relative to $35<$ age $\leq 45$} \\
\hline $14 \leq$ age $\leq 20$ & $\begin{array}{c}0.0021 * * \\
(0.0009)\end{array}$ & $\begin{array}{c}-0.0227^{* * *} \\
(0.0018)\end{array}$ & $\begin{array}{c}0.0071 * * * \\
(0.0009)\end{array}$ \\
\hline $20<$ age $\leq 25$ & $\begin{array}{l}-0.0011^{*} \\
(0.0006)\end{array}$ & $\begin{array}{l}-0.0105^{* * *} \\
(0.0010)\end{array}$ & $\begin{array}{c}-0.0024 * * * \\
(0.0005)\end{array}$ \\
\hline $25<$ age $\leq 35$ & $\begin{array}{c}0.0011^{* * * *} \\
(0.0003)\end{array}$ & $\begin{array}{c}0.0023 * * * \\
(0.0005)\end{array}$ & $\begin{array}{l}-0.0010^{* * *} \\
(0.0002)\end{array}$ \\
\hline $45<$ age $\leq 55$ & $\begin{array}{c}-0.0018^{* * *} \\
(0.0003)\end{array}$ & $\begin{array}{c}-0.0016 * * * \\
(0.0004)\end{array}$ & $\begin{array}{c}0.0002 \\
(0.0002)\end{array}$ \\
\hline $55<$ age $\leq 60$ & $\begin{array}{l}-0.0015 * * * \\
(0.0004)\end{array}$ & $\begin{array}{l}-0.0031 * * * \\
(0.0006)\end{array}$ & $\begin{array}{c}0.0004 \\
(0.0003)\end{array}$ \\
\hline $60<$ age $\leq 70$ & $\begin{array}{l}-0.0131 * * * \\
(0.0005)\end{array}$ & $\begin{array}{l}-0.0061 * * * \\
(0.0007)\end{array}$ & $\begin{array}{c}-0.0023 * * * \\
(0.0003)\end{array}$ \\
\hline $\begin{array}{l}\text { FOREIGN BORN: relative to born in } \\
\text { Netherlands }\end{array}$ & $\begin{array}{c}-0.0016 * * * \\
(0.0004)\end{array}$ & $\begin{array}{c}-0.0034 * * * \\
(0.0006)\end{array}$ & $\begin{array}{c}-0.0019 * * * \\
(0.0003)\end{array}$ \\
\hline \multicolumn{4}{|c|}{$\begin{array}{l}\text { HOUSEHOLD COMPOSITION: relative to } \\
\text { single and no kids } \leq 18 \text { years }\end{array}$} \\
\hline Single, child aged $\leq 4$ years & $\begin{array}{l}-0.0021 \\
(0.0022)\end{array}$ & $\begin{array}{c}0.0039 \\
(0.0039)\end{array}$ & $\begin{array}{l}-0.0001 \\
(0.0016)\end{array}$ \\
\hline Single, $4<$ child age $\leq 12$ & $\begin{array}{c}0.0033^{* * *} * \\
(0.0010)\end{array}$ & $\begin{array}{c}0.0016 \\
(0.0020)\end{array}$ & $\begin{array}{c}0.0018^{* *} \\
(0.0009)\end{array}$ \\
\hline Single, $12<$ child age $\leq 18$ & $\begin{array}{c}0.0061 * * * \\
(0.0008)\end{array}$ & $\begin{array}{c}0.0010 \\
(0.0016)\end{array}$ & $\begin{array}{c}0.0011 \\
(0.0008)\end{array}$ \\
\hline Partnered, no kids $\leq 18$ years & $\begin{array}{c}0.0013^{* * *} \\
(0.0003)\end{array}$ & $\begin{array}{c}0.0020^{* * *} \\
(0.0005)\end{array}$ & $\begin{array}{c}0.0003 \\
(0.0002)\end{array}$ \\
\hline Partnered, child aged $\leq 4$ years & $\begin{array}{c}0.0006 \\
(0.0004)\end{array}$ & $\begin{array}{l}0.0012 * * \\
(0.0006)\end{array}$ & $\begin{array}{c}-0.0007^{* *} \\
(0.0003)\end{array}$ \\
\hline Partnered, $4<$ child age $\leq 12$ & $\begin{array}{c}0.0005 \\
(0.0004)\end{array}$ & $\begin{array}{c}-0.0007 \\
(0.0006)\end{array}$ & $\begin{array}{c}0.0007 * * \\
(0.0003)\end{array}$ \\
\hline Partnered, $12<$ child age $\leq 18$ & $\begin{array}{l}0.0015^{* * *} \\
(0.0004)\end{array}$ & $\begin{array}{l}-0.0002 \\
(0.0006)\end{array}$ & $\begin{array}{c}0.0011 * * * \\
(0.0003)\end{array}$ \\
\hline \multicolumn{4}{|c|}{ CONTRACT: relative to permanent contract } \\
\hline Fixed contract & $\begin{array}{l}-0.0187 * * * \\
(0.0003)\end{array}$ & $\begin{array}{l}-0.0096 * * * \\
(0.0005)\end{array}$ & $\begin{array}{c}-0.0030 * * * \\
(0.0002)\end{array}$ \\
\hline Other contract & $\begin{array}{l}-0.0179 * * * \\
(0.0005)\end{array}$ & $\begin{array}{l}-0.0022 * * * \\
(0.0005)\end{array}$ & $\begin{array}{c}-0.0154 * * * \\
(0.0005)\end{array}$ \\
\hline $\begin{array}{l}\text { TYPE OF JOB: relative to regular j } \\
\text { Flexible job }\end{array}$ & $-0.0233 * * *$ & $-0.0426 * * *$ & $-0.0117 * * *$ \\
\hline Payrolling job & $\begin{array}{l}-0.0253^{* * *} \\
(0.0016)\end{array}$ & $\begin{array}{c}-0.0704 * * * \\
(0.0038)\end{array}$ & $\begin{array}{c}-0.0134 * * * \\
(0.0014)\end{array}$ \\
\hline Intern & $\begin{array}{c}-0.0123^{* * *} \\
(0.0019)\end{array}$ & $\begin{array}{c}-0.0185 * * * \\
(0.0041)\end{array}$ & $\begin{array}{c}-0.0484 * * * \\
(0.0043)\end{array}$ \\
\hline Sheltered employment & $\begin{array}{c}-0.0052^{* * *} \\
(0.0005)\end{array}$ & $\begin{array}{l}-0.0005 \\
(0.0006)\end{array}$ & $\begin{array}{c}0.0048 * * * \\
(0.0004)\end{array}$ \\
\hline
\end{tabular}




\begin{tabular}{lccc}
\hline & $\begin{array}{c}\text { Employment } \\
(=1)\end{array}$ & $\begin{array}{c}\text { Working hours } \\
(\log )\end{array}$ & $\begin{array}{c}\text { Hourly wage } \\
(\log )\end{array}$ \\
& $(1)$ & $(2)$ & $(3)$ \\
\hline FT/PT STATUS: relative to $\geq 35$ work hours a & & & \\
week & $-0.0018^{* * * *}$ & $-0.0031^{* * *}$ & $-0.0010^{* * *}$ \\
$20 \leq$ hours a week $<35$ & $(0.0003)$ & $(0.0005)$ & $(0.0003)$ \\
& $-0.0244 * * *$ & $-0.0328^{* * *}$ & $-0.0032^{* * *}$ \\
& $(0.0005)$ & $(0.0009)$ & $(0.0004)$ \\
\hline Hours a week $<20$ & $5,347,022$ & $5,347,005$ & $5,337,777$ \\
& $55,968,534$ & $54,330,091$ & $54,024,324$ \\
\hline Number of individuals & &
\end{tabular}




\section{Appendix B: Supplementary figures}
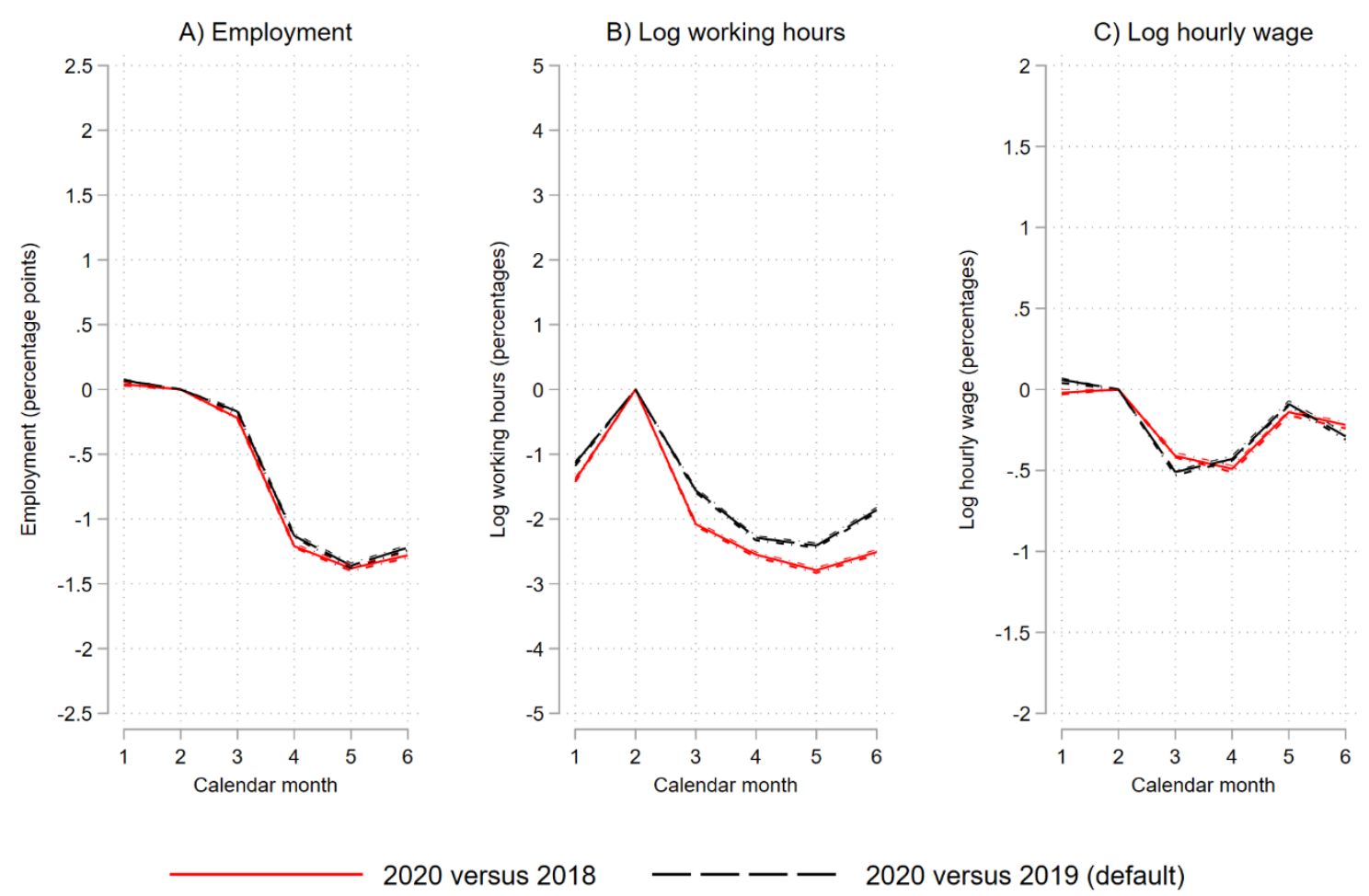

Figure B.1 - COVID-19 Differences-in-Differences effects on employment, log hours worked and log hourly wages (Equation (1)); using different reference years

Notes: Parameter estimates of the double interaction terms between year and calendar month. Each graph represents a different outcome variable and each line represents a single regression: one with reference year 2018 (the red solid line) and one with reference year 2019 (the black dashed line). Reference calendar month is 2 (February). The 95\% confidence intervals (the lighter dashed lines of the same colour) are computed based on standard errors clustered by individual. The number of individuals included in the regression is 8,640,068 for reference year 2018 and 8,415,590 for reference year 2019. 
Figure B. 2 shows that, on average, non-essential workers experience a reduction in working hours of 3 hours and in hourly wages of 0.3 euro in the period April-June 2020. Relative to their respective sample means in February 2020 (see Table A.3 of Appendix A), this equals a reduction of 2 to 3 per cent in working hours and 1 to 2 per cent in hourly wages.
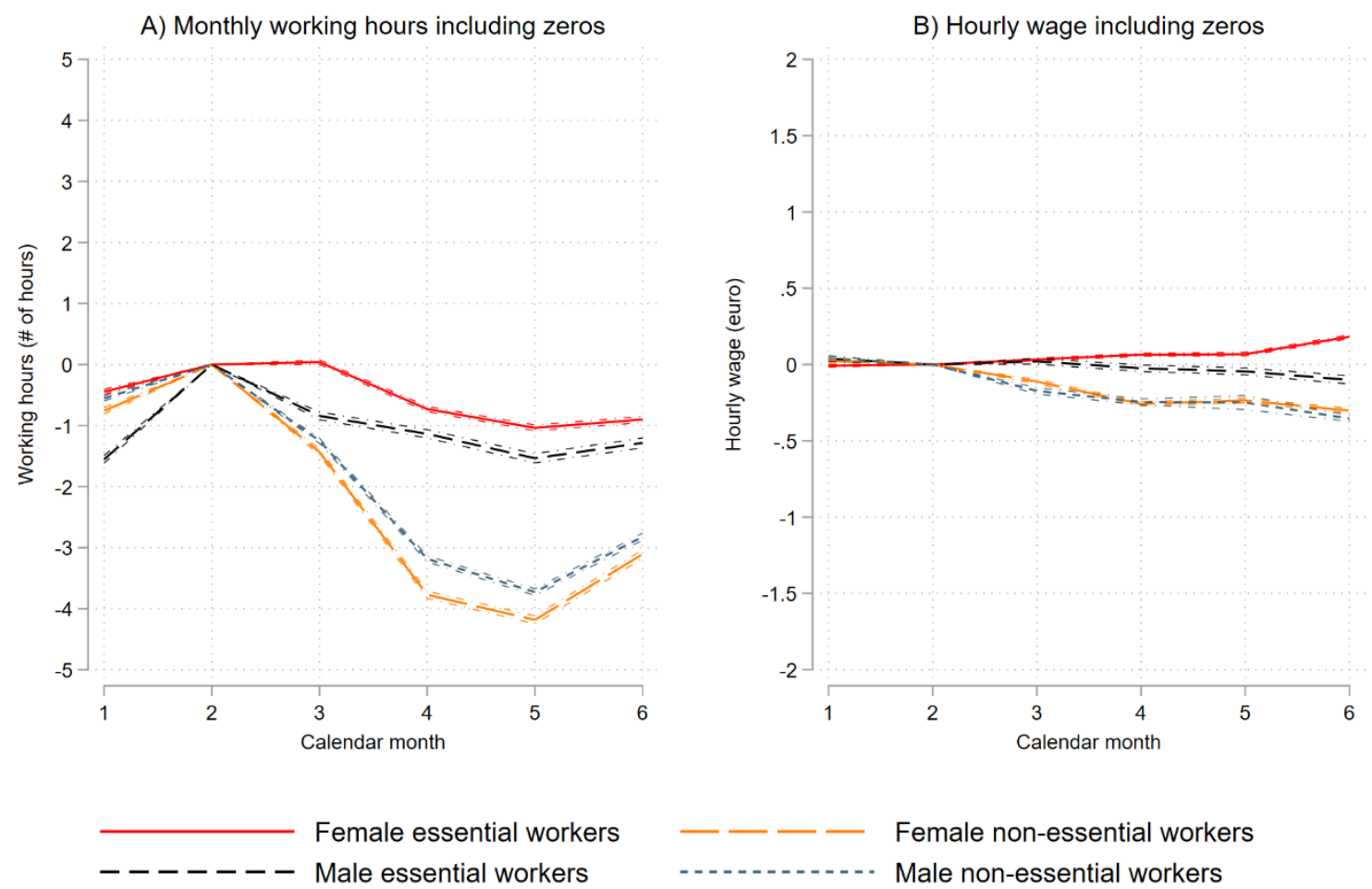

Figure B.2 - COVID-19 Differences-in-Differences effects on hours worked and hourly wages including zeros for the unemployed (Equation (1)); stratified by gender and by essential worker status Notes: Parameter estimates of the double interaction terms between year and calendar month. Each outcome variable is in levels and zeros are used for unemployed individuals. Each graph represents a different outcome variable and each line represents a single regression for a different sample stratified by gender and by essential worker status. Reference year is 2019 and reference calendar month is February. The 95\% confidence intervals are computed based on standard errors clustered by individual. The number of individuals included is 2,147,503 for female essential workers; 2,085,240 for female non-essential workers; 1,272,304 for male essential workers; and $3,261,782$ for male non-essential workers. 

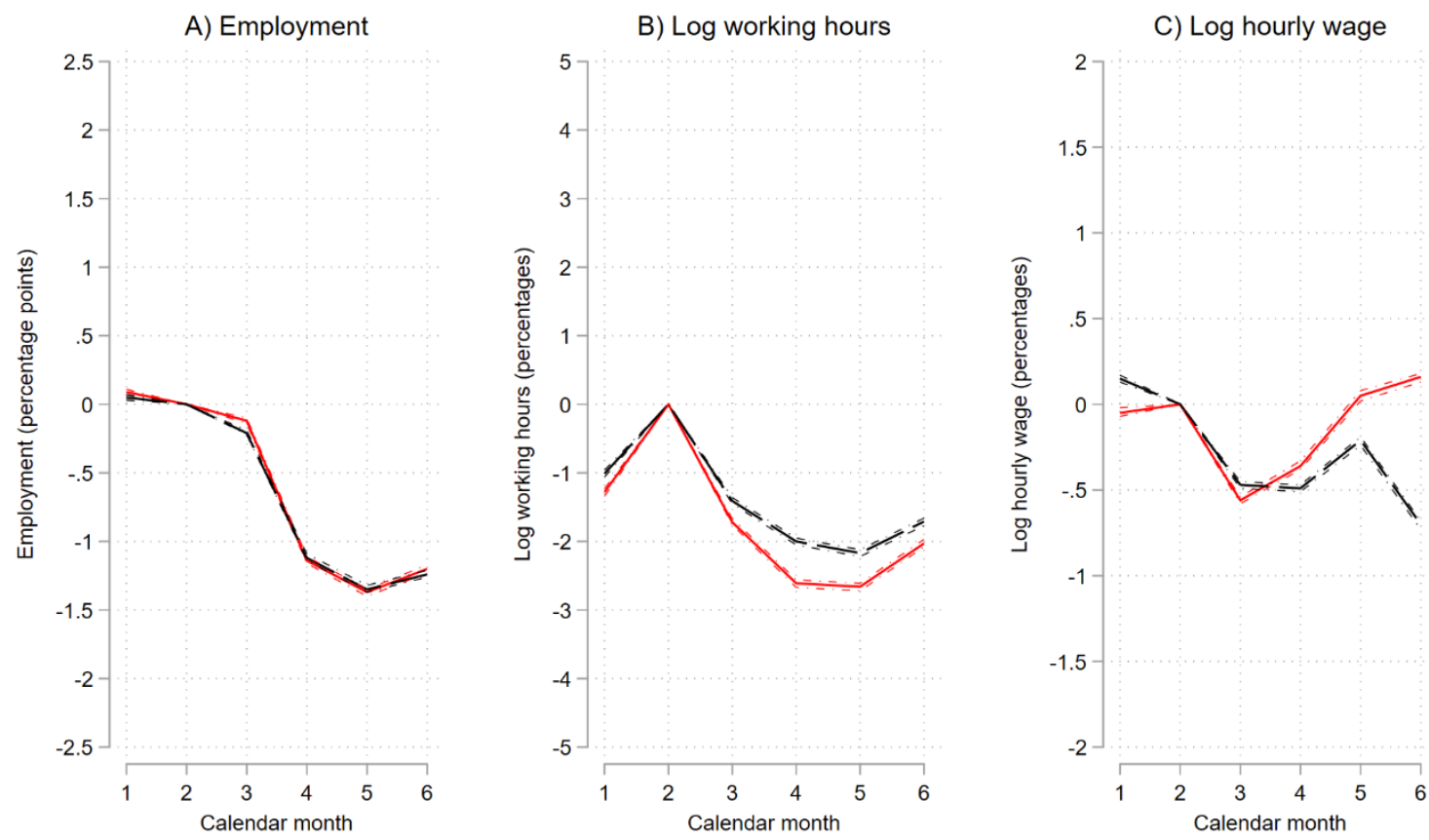

Female workers

Male workers

Figure B.3 - COVID-19 Differences-in-Differences effects on employment, log hours worked and log hourly wages (Equation (1)); stratified by gender (2020 compared to 2019)

Notes: Parameter estimates of the double interaction terms between year and calendar month. Each graph represents a different outcome variable and each line represents a single regression for a different sample stratified by gender. Reference year is 2019 and reference calendar month is 2 (February). The $95 \%$ confidence intervals (the lighter dashed lines of the same colour) are computed based on standard errors clustered by individual. The number of individuals included is 4,040,853 for female workers and 4,374,737 for male workers. Note that, for example, the total number of female workers is lower than the number of female essential workers plus the number of female non-essential workers, as employees could switch essential/non-essential worker status between February 2019 and February 2020 and would be counted as one individual when counting female workers regardless of their essential/non-essential status. 

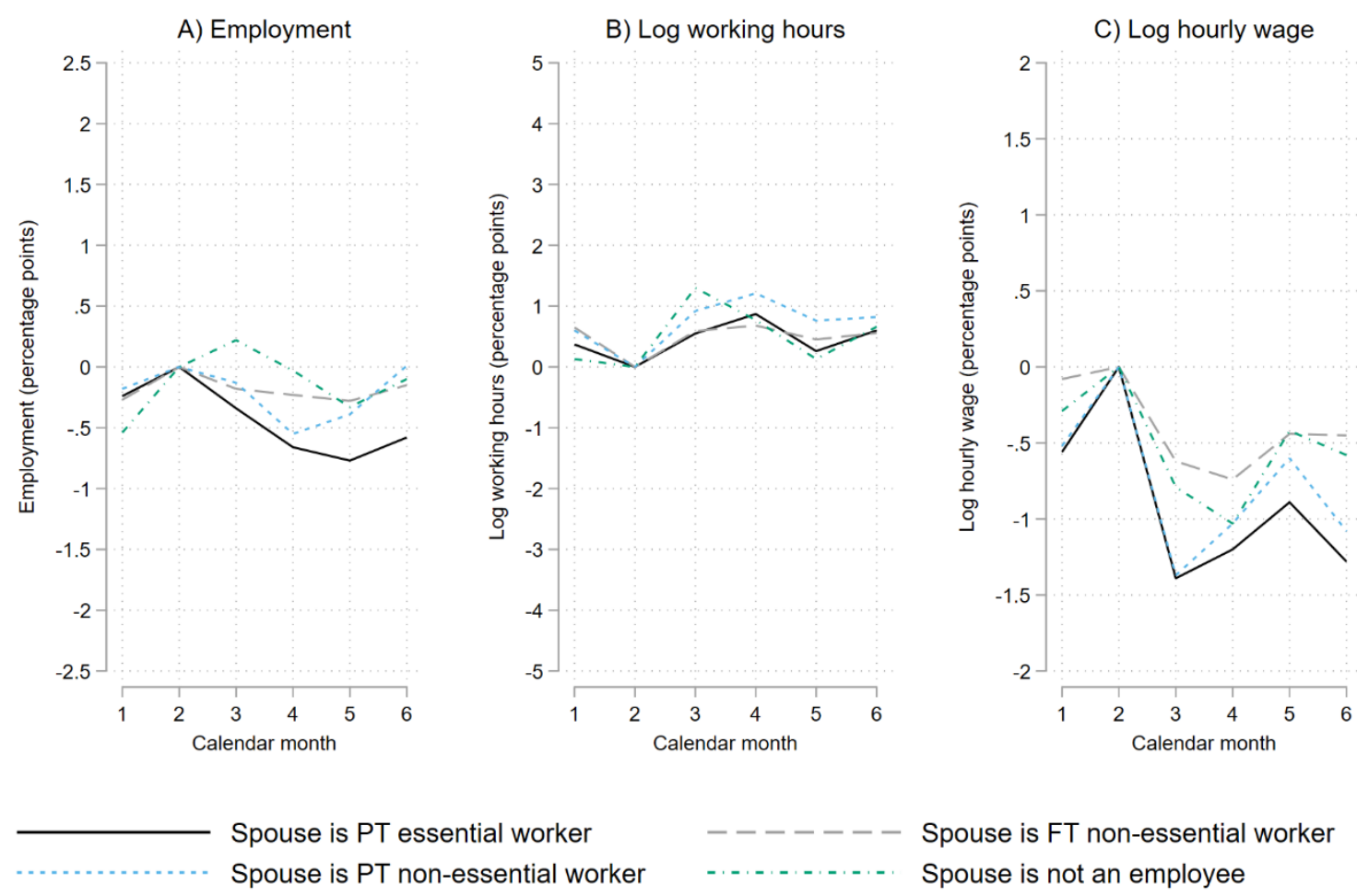

Figure B.4 - COVID-19 triple differences effects on employment, log hours worked and log hourly wages based on the triple interaction term between spouse's employment status, year and month (Equation (2)); for female essential full-time employees

Notes: Parameter estimates of the triple interaction terms between spouse's employment status, year and calendar month based on the sample of 55,510 female essential full-time employed workers who are partnered and have a child under 12 years of age. Each graph represents a different outcome variable based on one single regression. Reference spousal employment status is a full-time employed essential worker, reference year is 2019 and reference calendar month is February. For clarity of the graphs, confidence intervals are left out (but available upon request). Parameter estimates of the main, double interaction and triple interaction terms between year, calendar month and other observables are also estimated. 

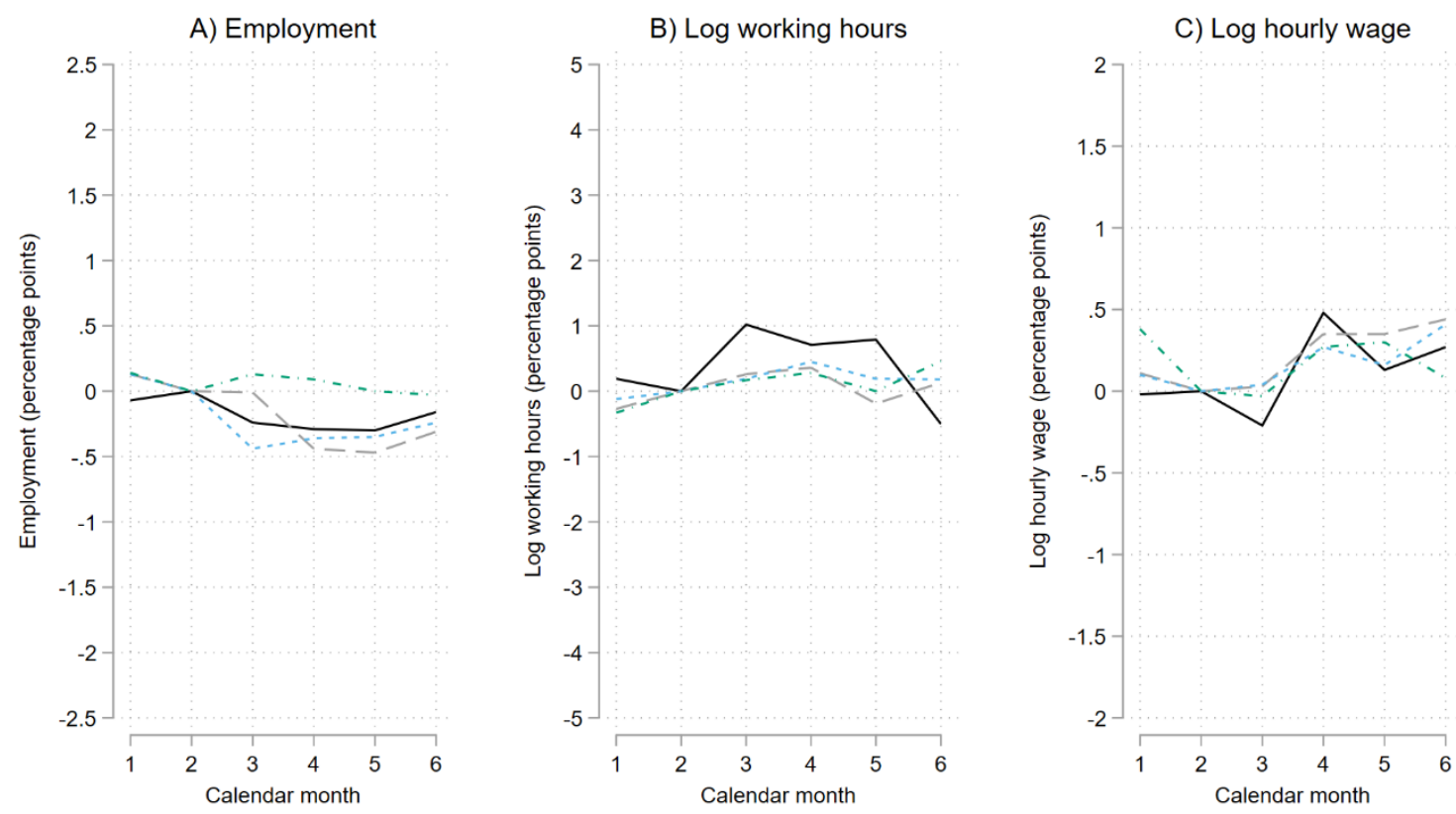

\section{Spouse is PT essential worker}

Spouse is FT non-essential worker

Spouse is PT non-essential worker

Spouse is not an employee

Figure B.5 - COVID-19 triple differences effects on employment, log hours worked and log hourly wages based on the triple interaction term between spouse's employment status, year and month (Equation (2)); for female non-essential full-time employees

Notes: Parameter estimates of the triple interaction terms between spouse's employment status, year and calendar month based on the sample of 87,147 female non-essential full-time employed workers who are partnered and have a child under 12 years of age. For other notes, see Figure B.4. 

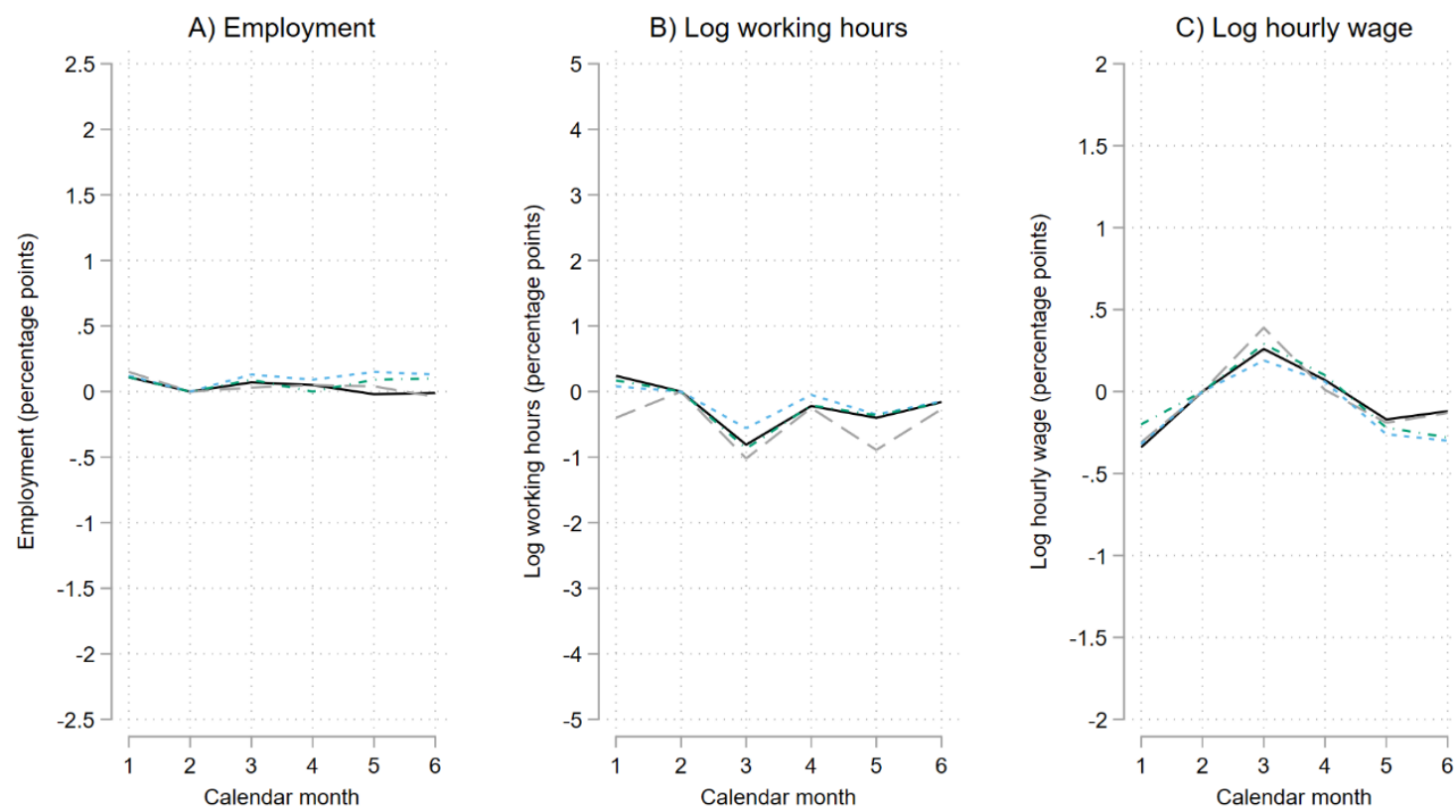

Spouse is PT essential worker

Spouse is FT non-essential worker

Spouse is PT non-essential worker

Spouse is not an employee

Figure B.6 - COVID-19 triple differences effects on employment, log hours worked and log hourly wages based on the triple interaction term between spouse's employment status, year and month (Equation (2)); for male essential full-time employees

Notes: Parameter estimates of the triple interaction terms between spouse's employment status, year and calendar month based on the sample of 200,286 male essential full-time employed workers who are partnered and have a child under 12 years of age. For other notes, see Figure B.4. 

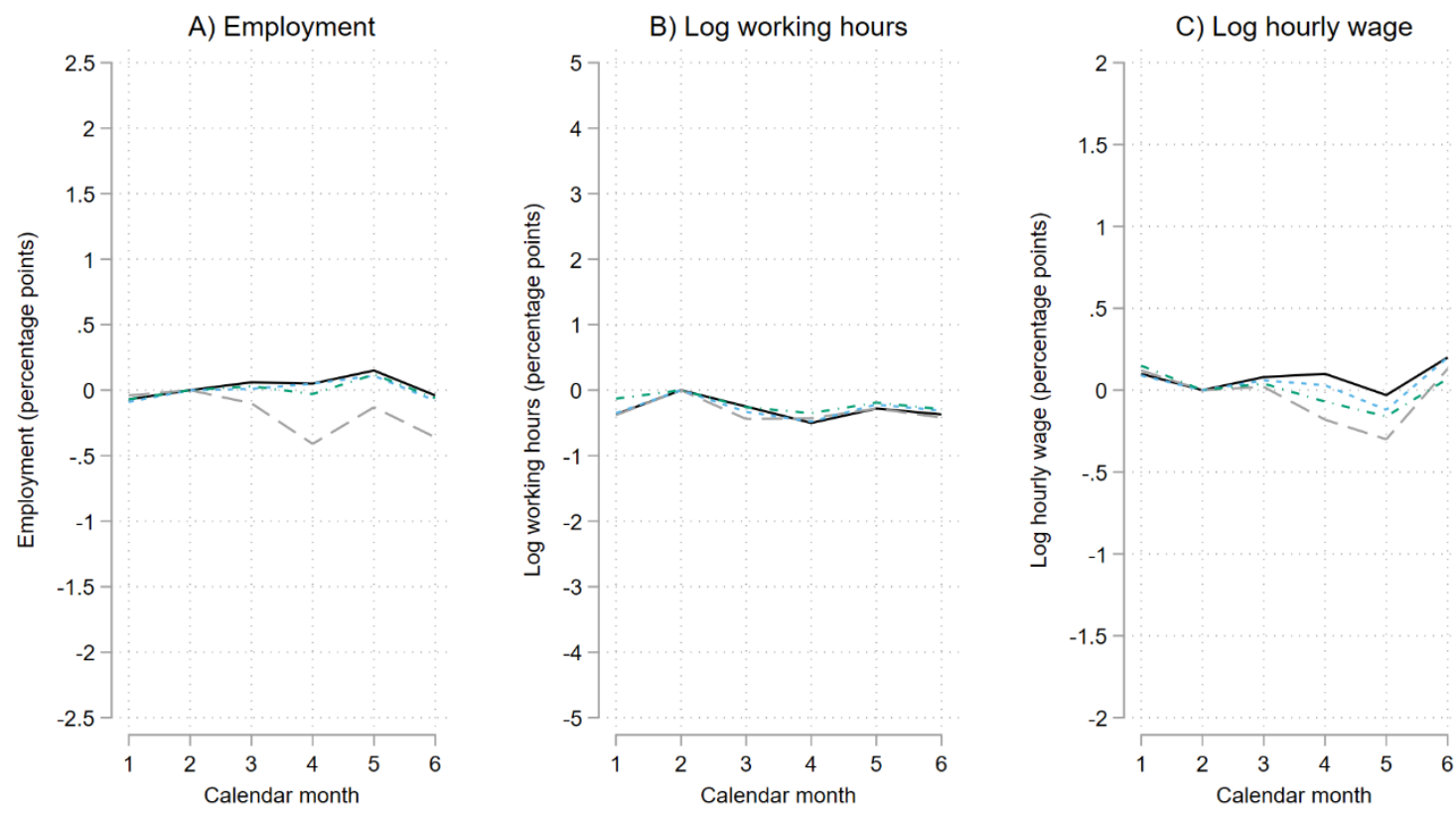

\section{Spouse is PT essential worker}

Spouse is FT non-essential worker

Spouse is PT non-essential worker

Spouse is not an employee

Figure B.7 - COVID-19 triple differences effects on employment, log hours worked and log hourly wages based on the triple interaction term between spouse's employment status, year and month (Equation (2)); for male non-essential full-time employees

Notes: Parameter estimates of the triple interaction terms between spouse's employment status, year and calendar month based on the sample of 600,906 male non-essential full-time employed workers who are partnered and have a child under 12 years of age. For other notes, see Figure B.4. 


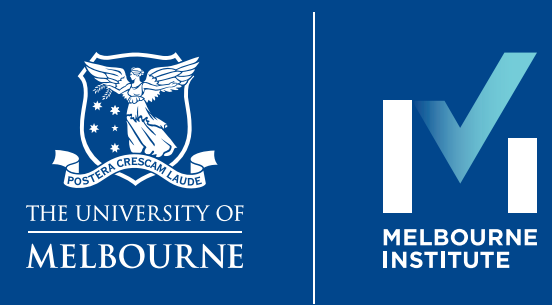




\section{University Library}

\section{- M M I E E R VA A gateway to Melbourne's research publications}

Minerva Access is the Institutional Repository of The University of Melbourne

Author/s:

Meekes, J;Hassink, WHJ;Kalb, G

Title:

Essential work and emergency childcare: Identifying gender differences in COVID-19 effects on labour demand and supply

Date:

2020

Citation:

Meekes, J., Hassink, W. H. J. \& Kalb, G. (2020). Essential work and emergency childcare: Identifying gender differences in COVID-19 effects on labour demand and supply.

Melbourne Institute: Applied Economic \& Social Research.

Persistent Link:

http://hdl.handle.net/11343/258512 